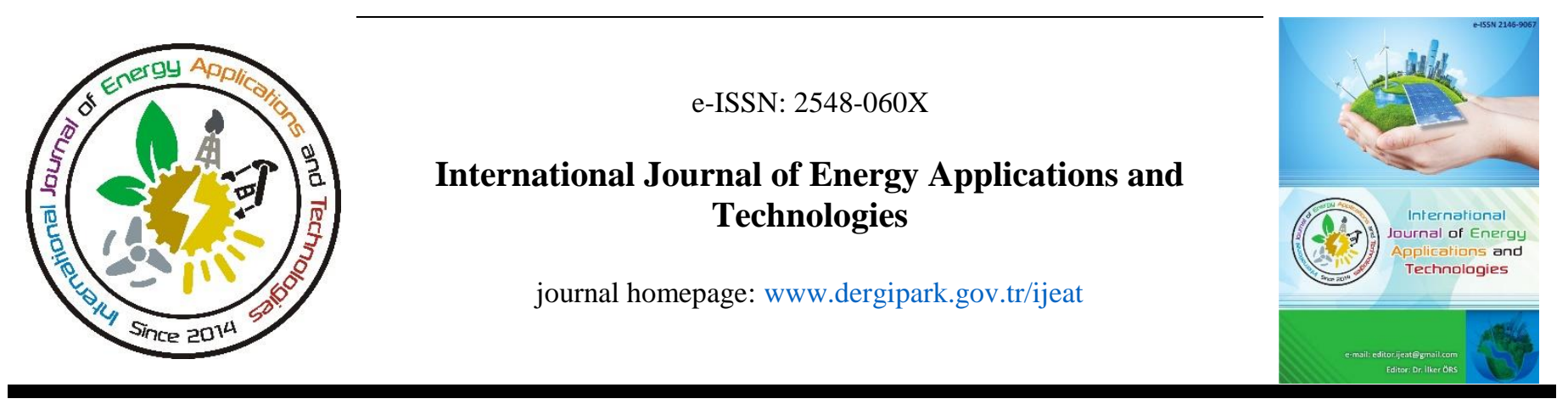

Original Research Article

\title{
Determination of optimum insulation thicknesses, energy savings and environmental impacts with respect to heating and cooling degree-days for different climate regions of Turkey
}

hosted by Jourkishall Park

\author{
Cenker Aktemur \\ Department of Mechanical Engineering, Eastern Mediterranean University, via Mersin 10, Famagusta, N.Cyprus, TURKEY
}

\author{
ARTICLE INFO \\ * Corresponding author \\ cenkeraktemur41@ @otmail.com \\ Received August 22, 2017 \\ Accepted March 30, 2018 \\ Published by Editorial Board \\ Members of IJEAT \\ (C) This article is distributed by \\ Turk Journal Park System under \\ the CC 4.0 terms and conditions.
}

\begin{abstract}
Choosing the most appropriate insulation material on the external walls of a building deserves serious attention. The present work is concerned with the economic and environmental assessment of using different insulation materials on the external walls of buildings located in four different degree-day regions. For this purpose, optimum insulation thicknesses were investigated for fiberglass, expanded polystyrene, glass wool and phenolic foam. Consequently, energy savings over a period of 10-years, payback periods, fuel consumptions and $\mathrm{CO}_{2}$ and $\mathrm{SO}_{2}$ emissions are determined for natural gas, coal and LPG. The annual heating and cooling energy required were estimated by using heating and cooling-degree days methodology. It is deduced that the cities of Antalya and Sanliurfa positioned in the first and second degree-day regions in Turkey, respectively, were not able to save energy for fiberglass as an insulation material with natural gas as fuel. The result demonstrated that the amount of energy savings fluctuates from 1.91 to $368.58 \mathrm{TL} / \mathrm{m} 2$ in the event of employing different fuel types for heating, change between 2.74 and $399 \mathrm{TL} / \mathrm{m} 2$ in case heating and cooling requirements are provided together at externally insulated walls of buildings. Payback period ranges from 0.081 to 3.28 years for heating and cooling together. Reductions in emissions fluctuate between 45.65-86.81 \% for coal, 31.0383.21\% for natural gas and 69.64-92.49\% for LPG.
\end{abstract}

Keywords: Energy saving, optimum insulation thickness, payback period, environmental impact, climate region

\section{Introduction}

Increasing industrialization in Turkey and individuals' desire for a better quality of life has resulted in increased energy consumption. Fossil fuels are primarily used to meet this growing energy need. However, there are two major problems with the use of fossil fuels; namely the possibility of depletion of these resources in the near future and environmental pollution caused by the use of fossil fuels in large quantities due to the concentration of industry in certain regions. To overcome these important energy issues, it is necessary to search for new sources of energy, develop new areas of use for existing resources and use existing resources efficiently [1].

In a country where a significant part of energy costs is realized in the building sector, energy efficiency is one of the most important issues to be addressed. Turkey, which aims to join the European Union, is making intensive efforts to reach the level of developed countries from the perspectives of technological advancement and socioeconomic status. With the population increase in this country, urbanization and industrialization have accelerated the energy consumption in Turkey compared to the past. However, since not enough attention is paid to the concept of productivity, energy is not used efficiently, leading to energy waste and importation on the one hand and pollution on the other [2]. It is clear that economic and environmental problems will be exacerbated in Turkey if energy saving measures are not put in place and sufficient applications are not developed in terms of the efficiency of energy use. In existing buildings, the energy consumption used for heating and cooling is quite 


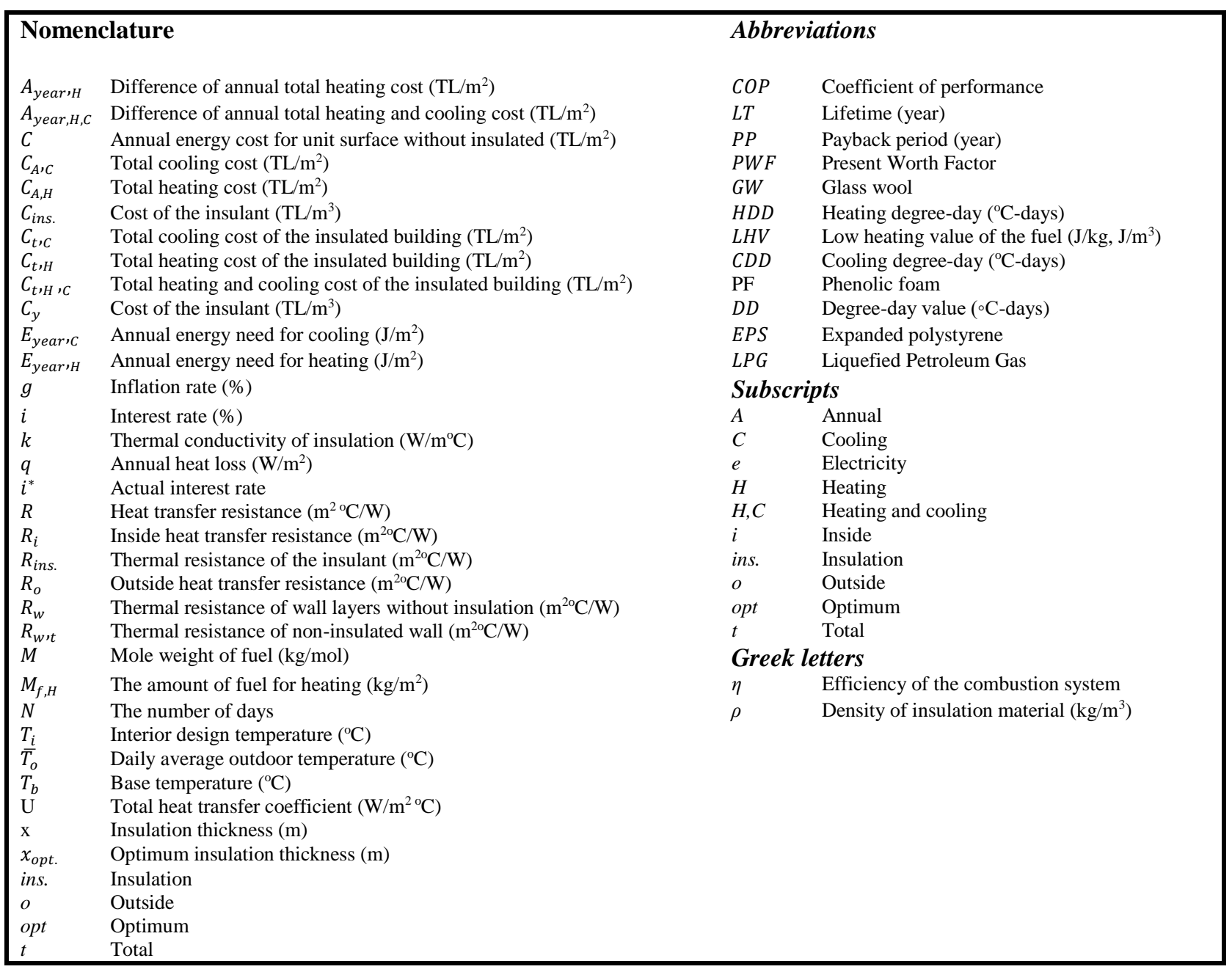

high. The energy consumed can be reduced to the minimum level by integrating passive heating and cooling elements into the building design. Insulating building walls using the most suitable insulation material is another saving method. It is possible to extend the life of buildings by providing heat insulation, thereby providing healthy, comfortable spaces for users and provide excellent savings in terms of heating and cooling expenses during the usage phase of the building. Large amounts of fossil fuels are used to warm these buildings, and the combustion of fossil fuels leads to air pollution and global warming. Thus, reducing the amount of energy used to create comfortable conditions with thermal insulation applications will help in preventing global warming and air pollution. Many countries have developed new building codes and standards since the 1970s, and these standards have undergone constant renewal due to continuous advancements in insulation technology [3]. For this reason, "Thermal Insulation Regulations in Buildings" (TS 825) were prepared in 1999 to intend to save energy by diminishing energy consumed in the heating and cooling of buildings, as this represents a significant share of the energy consumption in the country. According to the standard,
Turkey is divided into four degree-day zones and the heating requirements are provided by coal and increasingly by natural gas.

Insulation thickness in buildings is a vital parameter in the design of exterior walls, as too low an insulation thickness allows heat to flow from the inside to the outside or vice versa, resulting in a negative effect on thermal comfort and energy savings. Increasing the insulation thickness in the walls reduces heat loss and subsequently heating load and fuel cost. However, an increase in insulation thickness also means an increase in insulation costs. The total cost, which is the sum of the costs of the fuel and the insulation, decreases to a certain value and then increases beyond that level. Therefore, it is important that determinations of the optimum insulation thickness also take into account, the environment in which the building is located, the type of fuel and the choice of insulation material [4].

\section{A Review on the Determination of Optimum Insulation Thickness}

Previous studies on the efficient use of energy reported in the literature were generally aimed at determining the optimum 
insulation thickness and simple payback period. Dombayc1 et al. [5] calculated the optimum insulation thickness for exterior walls based on the number of degree-days when different sources of energy were used for heating in the buildings in Denizli. When evaluation is made according to the optimum insulation thickness, energy saving and payback period are set at $14.09 \mathrm{TL} / \mathrm{m}^{2}$ and 1.43 years, respectively. Bolattürk [6] calculated optimum insulation thicknesses, energy savings and payback periods for sixteen different cities selected from four different climate regions of Turkey. As a result of the calculation, it was observed that these values varied between $0.02-0.17 \mathrm{~m}, 22-79 \%$ and $1.3-4.5$ years, respectively. Daouas [7] studied the effect of different wall orientations on costs for both heating and cooling loads in Tunisia. The study demonstrated that the most economical result was obtained for the south oriented wall. Çomaklı and Yüksel [8] determined optimum insulation thicknesses, energy savings and payback periods for cities located in cold climatic regions of Turkey based on life-cycle cost analysis. Hasan [9] used the life-cycle method to determine the optimum insulation thickness. As a result of the study, the payback period was determined as 1-1.7 years for rock wool and 1.3-2.3 years for polystyrene. The results also showed energy saving of $21 \mathrm{TL} / \mathrm{m}^{2}$ for both polystyrene and rockwool. Mohsen and Akash [10] investigated the energy saving by using polystyrene, rock wool and air gap as insulation materials. The energy savings for polystyrene, rock wool and air gap were determined as $36 \%, 34 \%$ and $5.4 \%$, respectively. Mohammed [11] made energy calculations for insulation materials, optimal insulation thickness and solar radiation for buildings in Qatar. Kaynakl1 [12] investigated the annual energy requirements of a sample building in Bursa for various architectural design features (air infiltration rate, glass type, etc.) based on the degree-hour values. In the study, the effect of the insulation thickness on the energy requirement and the total cost were investigated. Based on the life cycle cost analysis, optimum insulation thickness was determined for different fuel types. Optimum insulation thickness was found between 5.3 and $12.4 \mathrm{~cm}$ depending on the different fuel types. Uçar and Balo [13] calculated the energy savings and payback periods over a

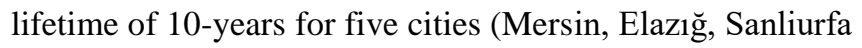
and Bitlis) in four different regions of Turkey and five different energy types (Coal, Natural Gas, Fuel oil, LPG, electricity) and four different insulation materials (Nil Siding, Ekpande Polistiren, Extruded Polystyrene, Stone Wool). The P1- $\mathrm{P}_{2}$ method was used in the calculations. Using a new approach, Ozkan and Onan [14] investigated the effects of altering the glazing area percentage of windows, which ranged from 10 to $50 \%$, on the optimum insulation thickness for four regions in Turkey.

\section{Methodology}

\subsection{The structure of buildings' external walls}

Heat is broadly lost from the building via the exterior walls, windows, floors and ceilings and by ingress of air from the exterior. Majority of heat is lost from buildings through exterior walls constructed of conventional building materials such as perforated bricks, concrete and wood. The thermal insulation on the outer walls is applied in three ways; internally, externally or sandwiched between two walls. An externally insulated wall to be employed in this study consists of $3.5 \mathrm{~cm}$ internal plaster, $23 \mathrm{~cm}$ horizontally perforated brick, insulation and $5 \mathrm{~cm}$ external plaster (Figure 1). A brief summary of physical and thermal properties of building construction materials is presented in Table 1 . The properties of various insulating materials to be employed throughout this study are given in Table 2.

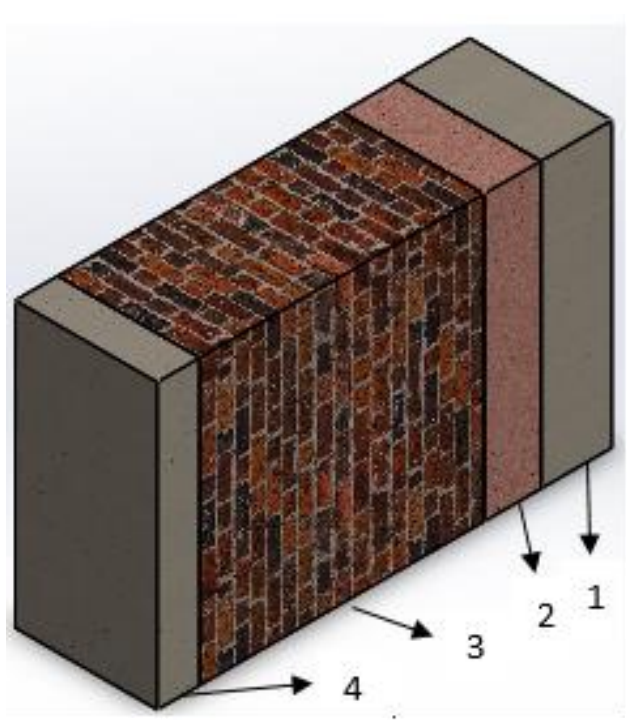

Figure 1. The structure of externally insulated wall modelled

Table 1. Physical and thermal properties of construction materials of the wall [15]

\begin{tabular}{lccc}
\hline \multicolumn{3}{c}{ Externally insulated wall } \\
\hline Wall element & Thickness, $\boldsymbol{x}$ & Conductivity, $\boldsymbol{k}$ & $\begin{array}{c}\text { Thermal } \\
\text { resistance } \\
\boldsymbol{R}\end{array}$ \\
\cline { 2 - 4 } & $(\mathbf{m})$ & $\left(\mathbf{W} / \mathbf{m}^{\mathbf{0}} \mathbf{C}\right)$ & $\left(\mathbf{m}^{\mathbf{2}} \mathbf{C} / \mathbf{W}\right)$ \\
\hline $\begin{array}{l}\text { Internal } \\
\text { plaster (1) }\end{array}$ & 0.035 & 0.87 & 0.040 \\
$\begin{array}{l}\text { Perforated } \\
\text { brick (3) }\end{array}$ & 0.23 & 0.45 & 0.511 \\
\hline Insulation (2) & See Table 2 for further information \\
\hline $\begin{array}{l}\text { External } \\
\text { plaster (4) }\end{array}$ & 0.05 & 0.87 & 0.052 \\
\hline $\begin{array}{l}\mathrm{R}_{\mathrm{i}} \\
\mathrm{R}_{\mathrm{o}}\end{array}$ & & & 0.13 \\
$\mathrm{R}_{\mathrm{w}, \mathrm{t}}$ & & & 0.04 \\
\hline
\end{tabular}


Table 2. Some properties of thermal insulation products

\begin{tabular}{|c|c|c|c|c|}
\hline $\begin{array}{c}\text { Insulation } \\
\text { material }\end{array}$ & Standard & $\begin{array}{c}\text { Density, } \\
\rho \\
\mathrm{kg} / \mathrm{m}^{3} \\
\end{array}$ & $\begin{array}{c}\text { Conductvity, } \\
k\end{array}$ & 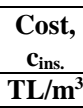 \\
\hline Fiberglass & - & - & 0.040 & 339 \\
\hline $\begin{array}{l}\text { Expanded } \\
\text { polystrene } \\
\text { (EPS) }\end{array}$ & $\begin{array}{l}\text { TS EN } \\
13163\end{array}$ & 16 & 0.035 & 110 \\
\hline $\begin{array}{l}\text { Glass wool } \\
(\mathrm{GW})\end{array}$ & $\begin{array}{l}\text { TS EN } \\
13167\end{array}$ & 45 & 0.032 & 105 \\
\hline $\begin{array}{l}\text { Phenolic } \\
\text { foam (PF) }\end{array}$ & $\begin{array}{l}\text { TS EN } \\
13166 \\
\end{array}$ & $35-200$ & 0.018 & 230 \\
\hline
\end{tabular}

\subsection{Degree-day concept}

The simplest method for energy analysis in buildings is degree-day (DD) method. The DD method gives precise and accurate results in terms of energy analysis. With the DD method, the required energy consumption for heating and cooling can be easily determined.

\subsubsection{Heating-degree day}

Heating degree-day (HDD) method is designed to forecast the energy needed to heat a building for thermal comfort. The difference between indoor and outdoor temperatures is HDD.
The value of HDD is determined using the following equation (1).

$$
H D D=\sum_{j=1}^{N}\left(T_{i}-\bar{T}_{o}\right)_{j} \quad \text { if }\left(\bar{T}_{o} \leq T_{b}\right)_{j}
$$

where $T_{i}$ and $T_{b}$ are, in turn, assumed to be constant and expressed as interior design temperature and base temperature. $\overline{T_{o}}$ is the daily average outdoor temperature measured at a meteorology station. $N$ is the number of days in a heating period when $\bar{T}_{o} \leq T_{b}$. Therefore, HDD is determined on the condition that $\bar{T}_{o} \leq T_{b}$.

\subsubsection{Cooling degree-day}

Cooling degree-day(CDD)method has been developed for cooling purposes. This method is employed to keep the indoor environment in comfort during hot weather. To ensure this comfort in hot weather, the interior must be cooled and ventilated. It is concluded that there is a direct proportional relationship between the amount of energy required and the CDDs [15].

$$
C D D=\sum_{j=1}^{N}\left(T_{i}-\bar{T}_{o}\right)_{j} \quad \text { if }\left(\overline{T_{o}} \leq T_{b}\right)_{j}
$$

Table 3. Climate regions and certain data for selected cities

\begin{tabular}{ccccccc}
\hline \multirow{2}{*}{ Zone } & City & Altitude & Longitude & Latitude & HDD & CDD \\
\cline { 3 - 7 } & & $(\mathbf{m})$ & $\left.\mathbf{(}^{\mathbf{0}}\right)$ & $\left.\mathbf{(}^{\mathbf{0}}\right)$ & $\mathbf{(}^{\mathbf{0}} \mathbf{C}$-day $)$ & $\left(^{\mathbf{0}} \mathbf{C}\right.$-day $)$ \\
\hline 1st & Antalya & 47.3 & 30.7 & 36.89 & 697 & 475 \\
2nd & Sanliurfa & 549.4 & 38.8 & 37.1 & 1070 & 761 \\
3rd & Konya & 1028.6 & 32.5 & 37.9 & 2294 & 176 \\
4th & Sivas & 1285 & 37 & 39.8 & 2739 & 109 \\
\hline
\end{tabular}

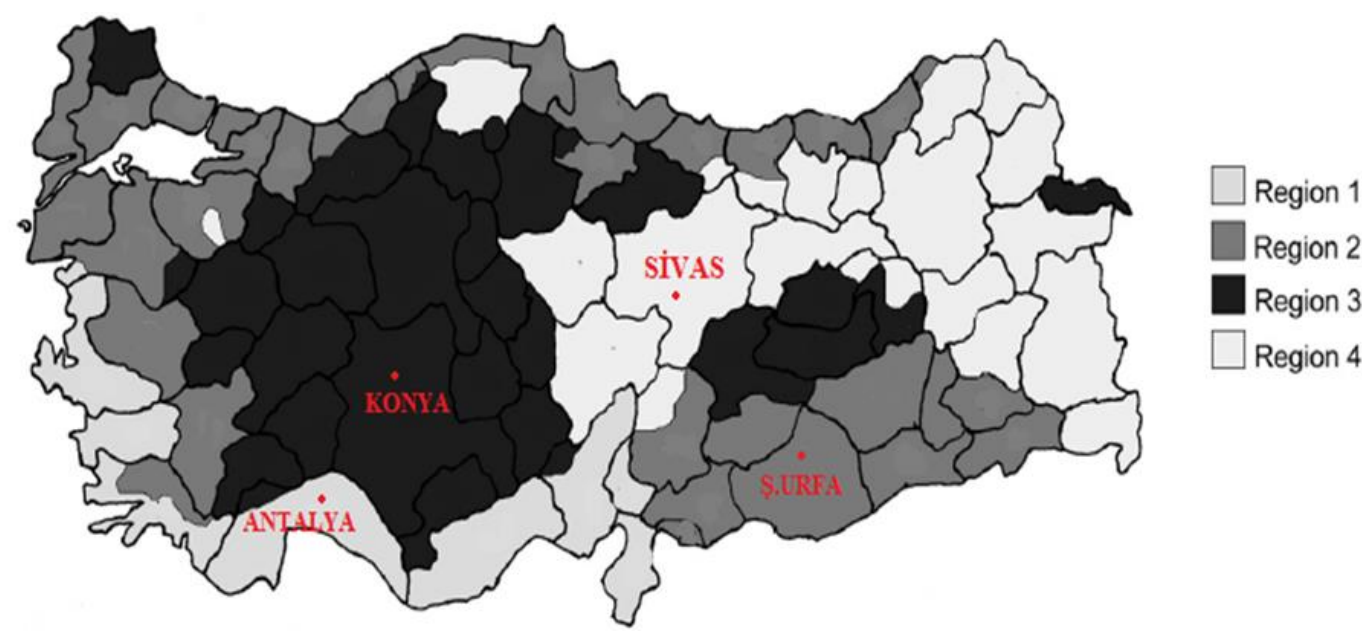

Figure 2. Degree-day zones characterized by TS 825 in Turkey

Turkey is divided into four climatic regions for each province according to DDs identified by TS 825 on the map indicated in Figure 2. Zone 1 represents the least energy requirement for heating and Zone 4 represents the region where energy is needed the most. In this study, the base temperature for heating and cooling purposes, in turn, is assumed as 15.5 and $24^{\circ} \mathrm{C}$ in order to calculate HDD and CDD values. A life-cycle cost analysis was performed for externally insulated wall 
structure using HDD and CDD values of Antalya, Sanliurfa, Konya and Sivas provincial centers, which are determined from four degree-day zones of Turkey. Detailed design of energy analysis in buildings has become imperative for optimum design and operation of heating and cooling systems. The basic need for calculation methods in energy analysis is detailed climate data. Energy efficiency can be ensured in buildings only when accurate and detailed climate data is available. However, climatic conditions can be drawn a random variation from year to year. Climate data is determined by examining meteorological values for past years. Therefore, daily maximum and minimum temperature data for 20years, from 1985 to 2005, were taken from the Directorate General of State Meteorology Affairs. Properties and number of heating and cooling degree-days of the cities referred to in this study are given in Table 3.

\subsection{Heating and cooling loads for external walls}

Heat losses in buildings are usually due to external wall surface, windows, roof and air infiltration. It is assumed that heat losses occur only at the outer wall surface. The heat loss from the unit surface of the outer wall is calculated with equation (3).

$$
q=U \times \Delta T
$$

where $U$ is the total heat transfer coefficient of the wall, $\Delta T$ is the difference between the outside ambient temperature and the constant inside ambient temperature. Using the HDD and CDD approaches, annual heat loss for a unit surface area can be found through equations (4) and (5).

$$
\begin{aligned}
& q_{\text {year }, H}=86400 \times H D D \times U \\
& q_{\text {year }, C}=86400 \times C D D \times U
\end{aligned}
$$

Total heat transfer coefficient for a typical wall is calculated as follows:

$$
U=\frac{1}{R_{i}+R_{W}+R_{\text {ins. }}+R_{o}}
$$

where $R_{i}$ and $R_{o}$ are the heat transfer coefficients on the inner and outer sides respectively, $R_{w}$ is the thermal resistance of the wall without insulation. The values of $R_{i}=0.13 \mathrm{~W} / \mathrm{m}^{2} \mathrm{~K}$ and $R_{o}=0.04 \mathrm{~m}^{2} \mathrm{~K} /$ Ware used for heat transfer coefficients on the inside and outside of the building. The thermal resistance of the insulation layer is determined as follows:

$$
R_{\text {ins. }}=\frac{x}{k}
$$

where $x$ and $k$ are the thickness and thermal conductivity coefficient of the insulation material, respectively.

The total thermal resistance of the non-insulated wall layer, $R_{w, t}$, is determined by help of the equation (8).

$$
R_{w, t}=R_{i}+R_{w}+R_{o}
$$

then, total heat transfer coefficient $U$ is expressed as in the following equation (9).

$$
U=\frac{1}{R_{w, t}+R_{\text {ins }} .}
$$

As a result, the annual energy required for heating and cooling purposes is calculated by aid of the equations (10) and (11), respectively [16].

$$
\begin{aligned}
& E_{\text {year }, H}=\frac{86400 \times H D D}{\left(R_{w, t}+R_{\text {ins. }}\right) \times \eta} \\
& E_{\text {year }, H}=\frac{86400 \times C D D}{\left(R_{w, t}+R_{\text {ins. }}\right) \times \mathrm{COP}}
\end{aligned}
$$

where COP is cooling system coefficient of performance, $\eta$ is efficiency of heating system.

\subsection{Calculation of the optimum insulation thickness and annular cost of energy}

By applying insulation to the exterior walls of the buildings, the heat gain and loss are significantly reduced. In this case, it is necessary to know the optimum thickness of insulation in terms of energy saving. Therefore, optimum insulation thickness should be determined by cost analysis. The annual fuel cost is obtained by multiplying the amount of fuel to be used per year by the unit price of the fuel. The annual cost of fuel for unit surface area, which is the unit price of the fuel, can be calculated with equations (12) and (13).

$$
\begin{aligned}
& E_{A, H}=E_{\text {year }, H} \times C_{\text {fuel }} \\
& E_{A, C}=E_{\text {year }, C} \times C_{e}
\end{aligned}
$$

The amount of fuel consumed per year is expressed for heating and cooling by using the equations (14) and (15).

$$
\begin{aligned}
& E_{A, H}=\frac{86400 \times H D D \times C_{f u e l}}{\left(R_{w, t}+R_{\text {ins }}\right) \times \eta \times \mathrm{LHV}} \\
& E_{A, C}=\frac{86400 \times C D D \times C_{e}}{\left(R_{w, t}+R_{\text {ins. }}\right) \times \mathrm{COP}}
\end{aligned}
$$

where LHV is Low Heating Value of the heating system, $\mathrm{C}_{\text {fuel }}$ is the unit fuel cost in $\mathrm{TL} / \mathrm{kg}, \mathrm{TL} / \mathrm{m}^{3}$ depending on the fuel type and $\mathrm{C}_{\mathrm{e}}$ is the cost of electricity in TL/kWh.

Another type of parameter to be used with selected wall type and insulation materials is the type of fuel. The most commonly used fuel types in selected cities are coal, natural gas, LPG (for hating) and electricity (for cooling). The characteristics of fuels selected for cooling and heating purpose in buildings are given in Table 4 . 
Table 4. Fuel costs $\left(C_{f u e l}\right)$ and low heating value (LHV) of heating systems, performances of cooling and heating systems and chemical formulas [17].

\begin{tabular}{lcccc}
\hline \multicolumn{1}{c}{ Fuel } & LHV & Performances & Cost & Chemical formula \\
\hline Coal & $29.295 \times 10^{6} \mathrm{~J} / \mathrm{kg}$ & $\eta=0.66$ & $0.94 \mathrm{TL} / \mathrm{kg}$ & $\mathrm{C}_{5.85} \mathrm{H}_{5.26} \mathrm{O}_{1.13} \mathrm{~S}_{0.008} \mathrm{~N}_{0.077}$ \\
Natural gas & $34.526 \times 10^{6} \mathrm{~J} / \mathrm{m}^{3}$ & $\eta=0.9$ & $1.08 \mathrm{TL} / \mathrm{m}^{3}$ & $\mathrm{C} 1.05 \mathrm{H} 4 \mathrm{O} 0.034 \mathrm{~N} 0.022$ \\
LPG & $46.453 \times 10^{6} \mathrm{~J} / \mathrm{kg}$ & $\eta=0.88$ & $6.8 \mathrm{TL} / \mathrm{kg}$ & $\mathrm{C}_{3.7} \mathrm{H}_{4.1}$ \\
Electricity (cooling) & - & $\mathrm{COP}=2.5$ & $0.42 \mathrm{TL} / \mathrm{kWh}$ & - \\
\hline
\end{tabular}

There are many economic analysis methods that can be used to evaluate investments. For the calculation of the optimum insulation thickness, Present Value Factor (PWF), which is one of the economic analysis methods, is used. PWF is a method of determining whether an investment is economical. During the economic life of the investment, all revenues and expenses are based on the basis of comparison by determining the sum of cash values over a specified interest rate. Expected Lifetime (LT) and the PWF must be evaluated together while calculating the total heating cost. PWF value depends on the actual interest rate (r) and time. The interest rate adjusted for inflation rate $\left(i^{*}\right)$ is given by equations (16) and (17) [18].

$$
\begin{array}{ll}
i^{*} & =\frac{i-g}{i+g}, \quad \text { for } \quad(i>g) \\
i^{*} & =\frac{i+g}{i-g}, \quad \text { for } \quad(i<g)
\end{array}
$$

where $\mathrm{g}$ is the inflation rate. In this case, PWF is determined by aid of the equation (18):

$$
P W F=\frac{\left(1+i^{*}\right)^{L T}-1}{i^{*}\left(1+i^{*}\right)^{L T}}
$$

where LT is the expected lifetime, which is taken to be 15 years. If $\mathrm{i}=\mathrm{g}$, then

$$
P W F=\frac{L T}{1+i}
$$

Lifetime, interest and inflation rate values employed in calculating the PWF are summarized in Table 5.

Table 5. Parameters used in the calculations [8]

\begin{tabular}{lc}
\hline Interest rate (i) & $9 \%$ \\
Inflation rate $(\mathrm{g})$ & $8.53 \%$ \\
Lifetime (LT) & 10 -years \\
Present worth factor (PWF) & 9.17 \\
\hline
\end{tabular}

Since the cost of insulation will increase in proportion to the unit thickness of the insulation material, the cost of insulation is given by equation (20).

$$
C_{\text {ins. }}=C_{y} \cdot x_{\text {ins. }}
$$

The total heating cost for an insulated building is calculated as follows:

$$
C_{t, H}=\frac{86400 \times H D D \times C_{f u e l} \times P W F}{\left(R_{w, t}+R_{\text {ins. }}\right) \times \eta \times \mathrm{LHV}}+C_{\text {ins. }} .
$$

The total cooling cost for an insulated building is calculated as follows:

$$
C_{t, C}=\frac{86400 \times C D D \times C_{f u e l} \times P W F}{\left(R_{w, t}+R_{i n s .}\right) \times \eta \times \mathrm{LHV}}+C_{i n s .}
$$

The total heating and cooling cost for an insulated building is calculated as follows:

$C_{t, H, C}=\frac{86400 \times H D D \times C_{f u e l} \times P W F}{\left(R_{w, t}+R_{\text {ins. }}\right) \times \eta \times \mathrm{LHV}}+\frac{86400 \times C D D \times C_{e} \times P W F}{\left(R_{W, t}+R_{\text {ins. }}\right) \times \mathrm{COP}}+C_{\text {ins. }}$

Optimum insulation thickness and minimizing the total heating cost is calculated with equation (24).

$X_{o p t, H}=293.94 \times\left(\frac{H D D \times C_{\text {fuel }} \times P W F \times k_{\text {ins }}}{L H V \times C_{y} \times \eta}\right)^{\frac{1}{2}}-k_{\text {ins }} \times R_{w, t}$

Optimum insulation thickness and minimizing the total cooling cost is calculated with equation (25).

$X_{o p t, C}=293.94 \times\left(\frac{C D D \times C_{e} \times P W F \times k_{i n s}}{C O P \times C_{y}}\right)^{\frac{1}{2}}-k_{\text {ins }} \times R_{w, t}$

Optimum insulation thickness and minimizing the total heating and cooling cost is calculated with equation (26) [1922].

$X_{\text {opt }, H, C}=293.94 \times\left(\frac{C D D \times C_{\text {fuel }} \times P W F \times k_{\text {ins }}}{L H V \times C_{y} \times \eta}+\right.$

$\left.\frac{C D D \times C_{e} \times P W F \times k_{i n s}}{C O P \times C_{y}}\right)^{\frac{1}{2}}-k_{i n s} \times R_{w, t}$

\subsection{Simple payback period}

In situations where interest rates vary, it is important to consider the period of payback as it is not possible to estimate the long-term interest rate. SPP is only meaningful for short periods (typically less than one year) as it does not take into account the time value of money. The simple payback period (SPP) is not a method of measuring the economic viability of an investment, but is a method that calculates how many 
years' incomes will meet expenses. The $\mathrm{C}_{\mathrm{H}, \mathrm{A}}$ and $\mathrm{C}_{\mathrm{H}, \mathrm{C}}$ in formula represents pre-insulation heating and heatingcooling energy costs. Annual total net saving amount for buildings heated is calculated with equation (27), annual total net saving amount for buildings heating and cooling with equation (28) and $\mathrm{SPP}_{\mathrm{H}}$ and $\mathrm{SPP}_{\mathrm{H}, \mathrm{C}}$ are calculated with equation (29) and (30), respectively.

$$
\begin{aligned}
& A_{\text {year }, H}=C_{H}-C_{t, H} \\
& A_{\text {year }, H, C}=C_{H, C}-C_{t, H, C} \\
& \mathrm{SPP}_{\mathrm{H}}=\frac{C_{\text {ins. }}}{A_{\text {year }, H}} \\
& \mathrm{SPP}_{\mathrm{H}, \mathrm{C}}=\frac{C_{\text {ins. }}}{A_{\text {year }, H, C}}
\end{aligned}
$$

\subsection{Calculation of annual combustion processes}

The heat loss from un-insulated buildings is quite high because no insulation is applied. This is why fuel consumption and therefore air pollution increases. The amount of fuel for heating required per year is expressed by using the following equation (31).

$$
M_{f, H}=\frac{86400 \times H D D}{\left(R_{w, t}+R_{\text {ins. }}\right) \times \eta \times \mathrm{LHV}}
$$

The general chemical formula for fuel is as follows:

$$
\begin{gathered}
C_{g} H_{y} \mathrm{O}_{z} \mathrm{~S}_{w} \mathrm{~N}_{t}+\alpha \mathrm{A}\left(\mathrm{O}_{2}+3.76 \mathrm{~N}_{2}\right) \\
(\alpha-1) \mathrm{AO}_{2}+\mathrm{wSO}_{2}+\mathrm{BN}_{2}
\end{gathered} \rightarrow g \mathrm{CO}_{2}+\left(\frac{y}{2}\right) \mathrm{H}_{2} \mathrm{O}+
$$

The constants $\mathrm{A}$ and $\mathrm{B}$ are calculated from the oxygen balance formulas given in (33) and (34) respectively:

$$
\begin{aligned}
A & =\left(g+\frac{y}{4}+w-\frac{z}{2}\right) \\
B & =3.76 \alpha\left(g+\frac{y}{4}+w-\frac{z}{2}\right)+\frac{t}{2}
\end{aligned}
$$

In equation (32), NOx and $\mathrm{CO}$ emissions are neglected. The emission amount of combustion products resulting from the combustion of $1 \mathrm{~kg}$ of fuel can be calculated as follow:

$$
\begin{aligned}
& M_{\mathrm{CO}_{2}}=\frac{g \mathrm{CO}_{2}}{M} \equiv \mathrm{kg} \mathrm{CO}_{2} / \mathrm{kg} \text { fuel } \\
& M_{\mathrm{SO}_{2}}=\frac{w \mathrm{SO}_{2}}{M} \equiv \mathrm{kg} \mathrm{SO}_{2} / \mathrm{kg} \text { fuel }
\end{aligned}
$$

where $\mathrm{M}$ is the fuel's mole weight and is calculated as follows:

$$
M=12 g+y+16 z+32 w+14 t \mathrm{~kg} / \mathrm{mol}
$$

The total amount of $\mathrm{CO}_{2}$ and $\mathrm{SO}_{2}$ emissions are calculated through the following equations (38) and (40).

$$
\begin{aligned}
& M_{\mathrm{CO}_{2}}=\frac{44 g}{M} M_{f, H} \\
& M_{\mathrm{CO}_{2}}=\frac{3,801,600 D D g}{M \eta \mathrm{LHV}}\left(\frac{k}{k R_{w, t}+x}\right) \mathrm{kg} / \mathrm{year} \\
& M_{\mathrm{SO}_{2}}=\frac{64 w}{M} M_{f, H} \\
& M_{\mathrm{SO}_{2}}=\frac{2,764,800 D D w}{M \eta \mathrm{LHV}}\left(\frac{k}{k R_{w, t}+x}\right) \mathrm{kg} / \mathrm{year}
\end{aligned}
$$

\section{Results and Discussion}

In this study, the optimum insulation thickness to be applied to exterior walls was calculated by considering HDD and CDD values. HDD and CDD methods are the basis for a long-accepted method used to create a 'normalized' or common denominator in energy usage. Optimum insulation thicknesses were calculated for four different types of fuel and insulation materials by selecting four cities from different climate zones in Turkey. By applying insulation material to the outer walls, optimum insulation thickness, energy saving and payback period are calculated according to the increasing insulation thicknesses. There are two parameters that affect the total annual cost of an insulated building. These are insulation and fuel costs. Ultimately, insulation and fuel expenses were identified as the central dimensions which impact the overall yearly expense associated with insulating a building, and it should be noted that the loss or gain of thermal energy is lowered for a building that has been insulated. Furthermore, the degree to which the applied insulation is thick is directly and proportionally correlated with the level of heat loss or gain, thereby meaning that overall expense falls in conjunction with a decrease in the thermal energy requirement to heat the unit area. Nevertheless, the fact should not be overlooked that the expense required applying insulation increases at an almost exponential rate when the thickness of the insulation rises.

Variation of both heating and cooling costs with insulation thickness of phenolic foam (PF) for externally insulated wall in case heating and cooling requirements are supplied by natural gas and electricity, respectively for selected cities over the 10-year life-time are shown in the following Figure 3(a-d). As seen from Figure 3, the insulation cost increases linearly while the fuel cost decreases with increasing insulation thickness. The total cost shows a similar tendency to change depending on the insulation thickness. Owing to the fact that Konya and Sivas are, in turn, situated in region 3 and 4, total cost for cooling is naturally at minimum level. Besides this, for the cities of Antalya and Sanliurfa, the total cost for cooling is at a desirable level due to their climate regions. 


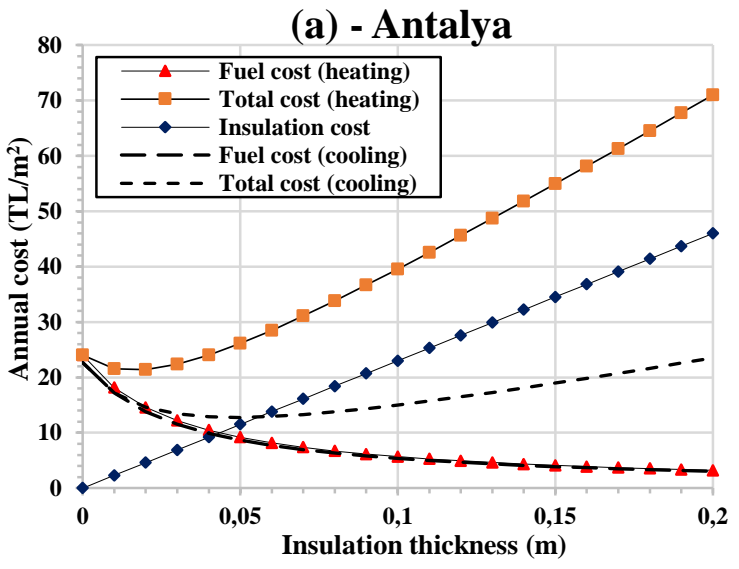

(c) - Konya

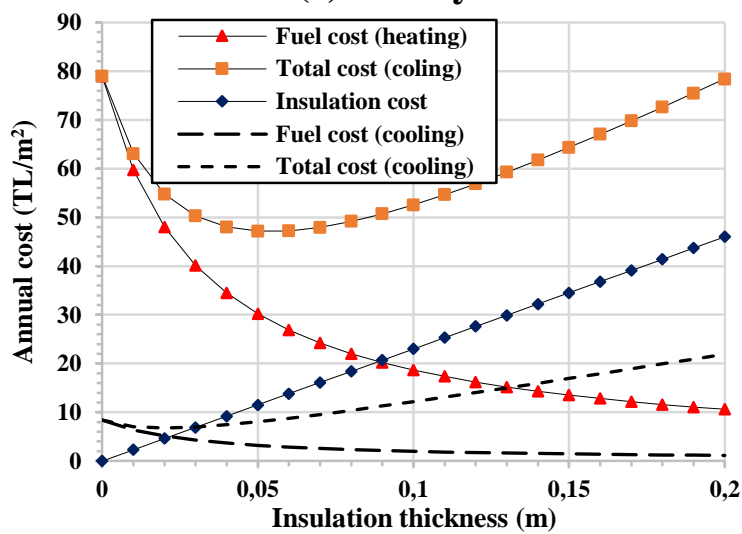

(b) - Sanliurfa

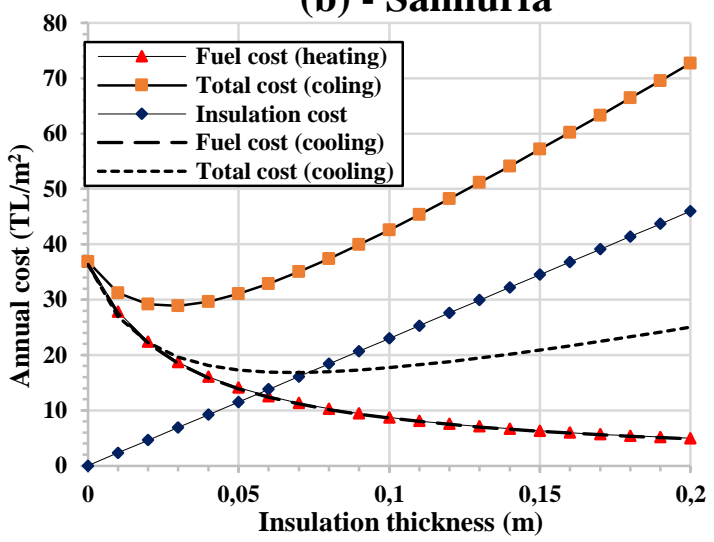

(d) - Sivas

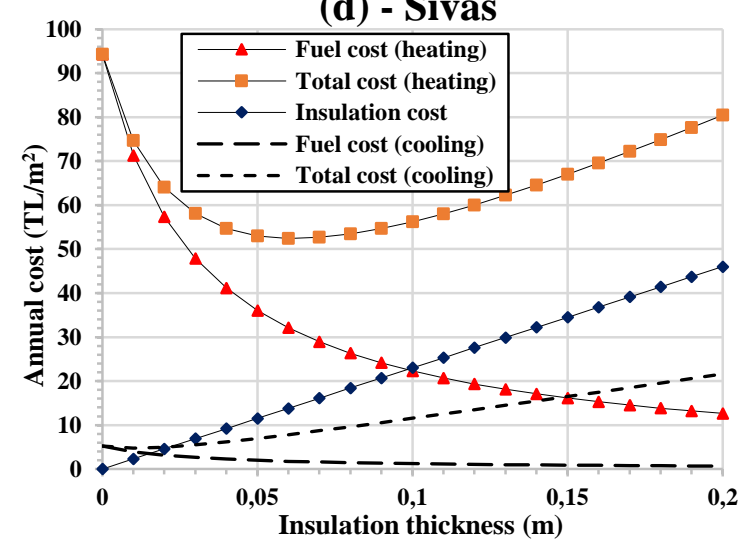

Figure 3. Variation of both heating and cooling costs with insulation thickness of phenolic foam in case of heating and cooling requirements are supplied by natural gas and electricity, respectively, in various provinces examined

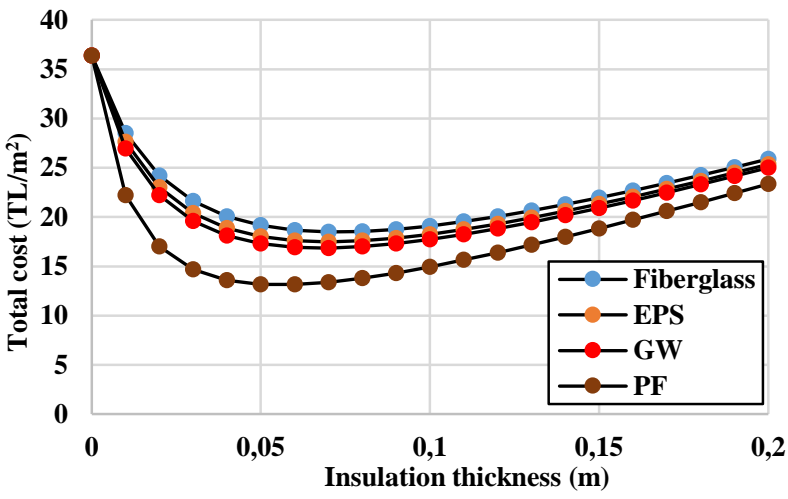

Figure 4. Alteration of total cooling cost with insulation thickness

Figure 4 indicates alteration of total cost with insulation thickness at externally insulated walls of buildings cooled only in city of Sanliurfa. The total cost of the phenolic foam as an insulation material with the lowest thermal conductivity among all insulation materials examined is minimized in Sanliurfa located in the second degree-day zone, whilst the total cost of fiberglass as an insulation material with the highest thermal conductivity is maximized. The change in energy saving by the enhancing thickness of four different insulation materials in the event of utilization of natural gas as an energy source in Konya is displayed in Figure 5. The energy saving of the phenolic foam as an insulation material with the lowest thermal conductivity among the insulation materials examined is maximized, while the minimum energy saving is achieved when the fiberglass as an insulation material with the highest thermal conductivity is used.

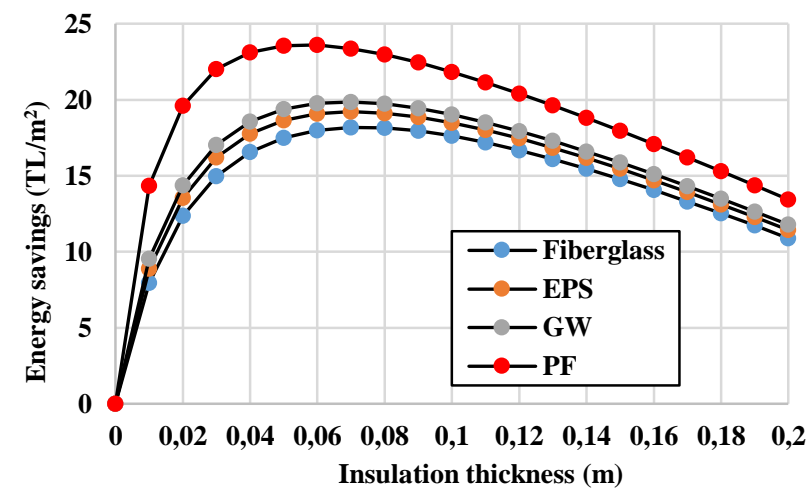

Figure 5. Energy savings with increased insulation thickness of different insulation materials in case heating requirement is using only natural gas in Konya

Optimum insulation thickness for different fuel types was calculated with equations (24)-(26). For heating, cooling, and both heating and cooling, optimum insulation thicknesses are provided in Table 6 for externally insulated walls. 
Table 6. Optimum insulation thickness by insulation types for various fuels in provinces examined

\begin{tabular}{|c|c|c|c|c|c|c|c|c|c|}
\hline \multicolumn{10}{|c|}{ Modeled External-type wall structure $\left(R_{w, t}=0.773 \mathrm{~m}^{2}-\mathrm{W} / \mathrm{K}\right)$} \\
\hline \multirow{2}{*}{ Antalya } & \multicolumn{3}{|c|}{ Natural gas } & \multicolumn{3}{|c|}{ Coal } & \multicolumn{3}{|c|}{ LPG } \\
\hline & $\mathbf{X}_{\mathrm{opt}, \mathrm{H}}$ & $\mathbf{X}_{\text {opt }, \mathrm{C}}$ & $\mathbf{X}_{\text {opt,H,C }}$ & $\mathbf{X}_{\mathrm{opt}, \mathrm{H}}$ & $\mathbf{X}_{\text {opt }, \mathrm{C}}$ & $\mathbf{X}_{\text {opt,H,C }}$ & $\mathbf{X}_{\text {opt,H }}$ & $\mathbf{X}_{\mathrm{opt}, \mathrm{C}}$ & $\mathbf{X}_{\text {opt }, \mathrm{H}, \mathrm{C}}$ \\
\hline Fiberglass & 0.014 & 0.012 & 0.032 & 0.026 & 0.012 & 0.042 & 0.071 & 0.012 & 0.08 \\
\hline EPS & 0.048 & 0.046 & 0.078 & 0.069 & 0.046 & 0.094 & 0.142 & 0.046 & 0.158 \\
\hline GW & 0.049 & 0.047 & 0.078 & 0.069 & 0.047 & 0.094 & 0.141 & 0.047 & 0.156 \\
\hline $\mathrm{PF}$ & 0.023 & 0.022 & 0.038 & 0.033 & 0.022 & 0.046 & 0.07 & 0.022 & 0.078 \\
\hline Sanliurfa & $\mathbf{X}_{\text {opt.H }}$ & $\mathbf{X}_{\text {opt.C }}$ & $\mathbf{X}_{\text {opt.H.C }}$ & $\mathbf{X}_{\text {opt.H }}$ & $\mathbf{X}_{\text {opt.C }}$ & $\mathbf{X}_{\text {opt.H.C }}$ & $\mathbf{X}_{\text {opt.H }}$ & $\mathbf{X}_{\text {opt.C }}$ & $\mathbf{X}_{\text {opt.H.C }}$ \\
\hline Fiberglass & 0.025 & 0.024 & 0.049 & 0.04 & 0.024 & 0.06 & 0.096 & 0.024 & 0.108 \\
\hline EPS & 0.066 & 0.066 & 0.105 & 0.092 & 0.066 & 0.124 & 0.183 & 0.066 & 0.203 \\
\hline GW & 0.067 & 0.066 & 0.105 & 0.092 & 0.066 & 0.124 & 0.181 & 0.066 & 0.201 \\
\hline $\mathrm{PF}$ & 0.032 & 0.032 & 0.052 & 0.045 & 0.032 & 0.061 & 0.09 & 0.032 & 0.1 \\
\hline Konya & $\mathbf{X}_{\text {opt.H }}$ & $\mathbf{X}_{\text {opt.C }}$ & $\mathbf{X}_{\text {opt.H.C }}$ & $\mathbf{X}_{\text {opt.H }}$ & $\mathbf{X}_{\text {opt.C }}$ & $\mathbf{X}_{\text {opt.H.C }}$ & $\mathbf{X}_{\text {opt.H }}$ & $\mathbf{X}_{\text {opt.C }}$ & $\mathbf{X}_{\text {opt.H.C }}$ \\
\hline Fiberglass & 0.052 & 0 & 0.056 & 0.075 & 0 & 0.078 & 0.156 & 0 & 0.158 \\
\hline EPS & 0.11 & 0.016 & 0.118 & 0.148 & 0.016 & 0.154 & 0.281 & 0.016 & 0.284 \\
\hline GW & 0.11 & 0.018 & 0.117 & 0.147 & 0.018 & 0.152 & 0.277 & 0.018 & 0.28 \\
\hline PF & 0.054 & 0.008 & 0.058 & 0.073 & 0.008 & 0.076 & 0.139 & 0.008 & 0.141 \\
\hline Sivas & $\mathbf{X}_{\mathrm{opt}, \mathrm{H}}$ & $\mathbf{X}_{\text {opt,C }}$ & $\mathbf{X}_{\text {opt,H,C }}$ & $\mathbf{X}_{\mathrm{opt}, \mathrm{H}}$ & $\mathbf{X}_{\mathrm{opt}, \mathrm{C}}$ & $\mathbf{X}_{\text {opt,H,C }}$ & $\mathbf{X}_{\mathrm{opt}, \mathrm{H}}$ & $\mathbf{X}_{\mathrm{opt}, \mathrm{C}}$ & $\mathbf{X}_{\text {opt,H,C }}$ \\
\hline Fiberglass & 0.06 & 0 & 0.062 & 0.085 & 0 & 0.087 & 0.173 & 0 & 0.174 \\
\hline EPS & 0.123 & 0.007 & 0.128 & 0.164 & 0.007 & 0.168 & 0.31 & 0.007 & 0.312 \\
\hline GW & 0.123 & 0.009 & 0.127 & 0.163 & 0.009 & 0.166 & 0.305 & 0.009 & 0.307 \\
\hline PF & 0.061 & 0.003 & 0.063 & 0.081 & 0.003 & 0.083 & 0.153 & 0.003 & 0,154 \\
\hline
\end{tabular}

Table 7. Optimum insulation thickness heated only, net saving amount and payback period

Modeled External-type wall structure $\left(R_{w, t}=0.773\right.$ m$\left.^{2}-W / K\right)$

\begin{tabular}{|c|c|c|c|c|c|c|c|c|c|c|}
\hline \multirow{3}{*}{ City } & \multirow{3}{*}{$\begin{array}{c}\text { Ins. } \\
\text { Material }\end{array}$} & \multicolumn{3}{|c|}{ Natural gas } & \multicolumn{3}{|c|}{ Coal } & \multicolumn{3}{|c|}{ LPG } \\
\hline & & $\mathrm{X}_{\mathrm{opt}, \mathrm{H}}$ & $\mathrm{A}_{\text {year, } \mathrm{H}}$ & $\mathrm{PP}_{\mathrm{H}}$ & $\mathrm{X}_{\mathrm{opt}, \mathrm{H}}$ & $\mathrm{A}_{\text {year, } \mathrm{H}}$ & $\mathrm{PP}_{\mathrm{H}}$ & $\mathrm{X}_{\mathrm{opt}, \mathrm{H}}$ & $\mathrm{A}_{\text {year, } \mathrm{H}}$ & $\mathrm{PP}_{\mathrm{H}}$ \\
\hline & & (m) & $\left(\mathrm{TL} / \mathrm{m}^{2}\right)$ & (year) & (m) & $\left(\mathrm{TL} / \mathrm{m}^{2}\right)$ & (year) & (m) & $\left(\mathrm{TL} / \mathrm{m}^{2}\right)$ & (year) \\
\hline \multirow{4}{*}{ 胥 } & Fiberglass & 0.014 & 1.905 & 2.491 & 0.026 & 7.043 & 1.251 & 0.071 & 51.463 & 0.468 \\
\hline & EPS & 0.048 & 8.684 & 0.608 & 0.069 & 17.810 & 0.426 & 0.142 & 76.388 & 0.204 \\
\hline & GW & 0.049 & 9.391 & 0.548 & 0.069 & 18.816 & 0.385 & 0.141 & 78.457 & 0.189 \\
\hline & PF & 0.023 & 8.299 & 0.637 & 0.033 & 17.256 & 0.440 & 0.07 & 75.238 & 0.214 \\
\hline \multirow{4}{*}{ 丞 } & Fiberglass & 0.025 & 6.310 & 1.343 & 0.04 & 16.724 & 0.811 & 0.096 & 93.891 & 0.347 \\
\hline & EPS & 0.066 & 16.632 & 0.436 & 0.092 & 31.989 & 0.316 & 0.183 & 126.698 & 0.159 \\
\hline & GW & 0.067 & 17.605 & 0.400 & 0.092 & 33.332 & 0.290 & 0.181 & 129.358 & 0.147 \\
\hline & $\mathrm{PF}$ & 0.032 & 16.097 & 0.457 & 0.045 & 31.246 & 0.331 & 0.09 & 125.215 & 0.165 \\
\hline \multirow{4}{*}{ 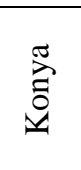 } & Fiberglass & 0.052 & 27.400 & 0.643 & 0.075 & 56.918 & 0.447 & 0.156 & 247.883 & 0.213 \\
\hline & EPS & 0.11 & 46.251 & 0.262 & 0.148 & 83.005 & 0.196 & 0.281 & 299.656 & 0.103 \\
\hline & GW & 0.11 & 47.864 & 0.241 & 0.147 & 85.161 & 0.181 & 0.277 & 303.740 & 0.096 \\
\hline & $\mathrm{PF}$ & 0.054 & 45.357 & 0.274 & 0.073 & 81.806 & 0.205 & 0.139 & 297.373 & 0.108 \\
\hline \multirow{4}{*}{$\stackrel{D}{\pi}_{\tilde{s}}^{\infty}$} & Fiberglass & 0.06 & 36.367 & 0.559 & 0.085 & 73.180 & 0.394 & 0.173 & 306.758 & 0.191 \\
\hline & EPS & 0.123 & 57.712 & 0.234 & 0.164 & 102.431 & 0.176 & 0.31 & 364.077 & 0.094 \\
\hline & GW & 0.123 & 59.512 & 0.217 & 0.163 & 104.825 & 0.163 & 0.305 & 368.577 & 0.087 \\
\hline & $\mathrm{PF}$ & 0.061 & 56.712 & 0.247 & 0.081 & 101.099 & 0.184 & 0.153 & 361.560 & 0.097 \\
\hline
\end{tabular}

Table 7 shows annual energy savings and payback periods for cities examined, in the event insulation materials are used at optimum thickness for heating only. Tables 8 shows annual energy savings and payback periods in consideration of optimum insulation thicknesses calculated by taking into account buildings both heated and cooled. When the two tables are reviewed, required insulation thickness for buildings heated and cooled is more than required insulation thickness for buildings heated only. In addition to this, energy savings at unit area increases and payback periods decrease. In the cases where natural gas is used as heating requirement in Antalya and Sanliurfa provinces, there will be no energy saving for fiberglass. 
For four examined provinces, variations of required optimum insulation thicknesses insulation materials to be used by fuels for heating only in cities are provided in Figures6and 7 for buildings both heated and cooled. By means of calculations made, required optimum insulation thicknesses according to heating degree-day values and type of insulant are provided in Figure 8. As heating degree-day values increase, required insulation thickness increases. Figure 9 shows required optimum insulation thicknesses by cooling degree-day values and type of insulant. Just like in heating, as degree-day values increase in cooling, required insulation thickness increases too.

Table 8. Optimum insulation thickness, net saving amount and payback period for both heating and cooling

\begin{tabular}{|c|c|c|c|c|c|c|c|c|c|c|}
\hline \multicolumn{11}{|c|}{ Modeled External-type wall structure $\left(R_{w, t}=0.773 \mathrm{~m}^{2}-\mathrm{W} / \mathrm{K}\right)$} \\
\hline \multirow{3}{*}{ City } & \multirow{3}{*}{$\begin{array}{c}\text { Ins. } \\
\text { Material }\end{array}$} & \multicolumn{3}{|c|}{ Natural gas } & \multicolumn{3}{|c|}{ Coal } & \multicolumn{3}{|c|}{ LPG } \\
\hline & & $\mathrm{X}_{\mathrm{opt}, \mathrm{H}, \mathrm{C}}$ & $\mathrm{A}_{\text {year, } \mathrm{H}, \mathrm{C}}$ & $\mathrm{PP}_{\mathrm{H}, \mathrm{C}}$ & $\mathrm{X}_{\mathrm{opt}, \mathrm{H}, \mathrm{C}}$ & $\mathrm{A}_{\text {year, H,C }}$ & $\mathrm{PP}_{\mathrm{H}, \mathrm{C}}$ & $\mathrm{X}_{\mathrm{opt}, \mathrm{H}, \mathrm{C}}$ & $\mathrm{A}_{\text {year, } \mathrm{H}, \mathrm{C}}$ & $\mathrm{PP}_{\mathrm{H}, \mathrm{C}}$ \\
\hline & & $(\mathrm{m})$ & $\left(\mathrm{TL} / \mathrm{m}^{2}\right)$ & (years) & $(\mathrm{m})$ & $\left.\mathrm{TL} / \mathrm{m}^{2}\right)$ & (year) & $(\mathrm{m})$ & $\left(\mathrm{TL} / \mathrm{m}^{2}\right)$ & (year) \\
\hline \multirow{4}{*}{ 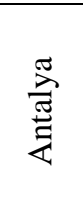 } & Fiberglass & 0.034 & -9.783 & 0 & 0.041 & -1.646 & 0 & 0.083 & 52.137 & 0.54 \\
\hline & EPS & 0.08 & 3.386 & 2.599 & 0.092 & 14.571 & 0.695 & 0.16 & 80.611 & 0.218 \\
\hline & GW & 0.08 & 4.559 & 1.843 & 0.092 & 15.973 & 0.605 & 0.158 & 82.934 & 0.2 \\
\hline & PF & 0.039 & 2.737 & 3.277 & 0.045 & 13.793 & 0.75 & 0.079 & 79.318 & 0.229 \\
\hline \multirow{4}{*}{ 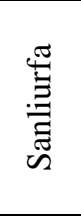 } & Fiberglass & 0.051 & -8.101 & 0 & 0.06 & 6.416 & 3.17 & 0.11 & 96.902 & 0.385 \\
\hline & EPS & 0.107 & 10.281 & 1.145 & 0.121 & 28.511 & 0.467 & 0.205 & 134.135 & 0.168 \\
\hline & GW & 0.107 & 11.845 & 0.948 & 0.121 & 30.361 & 0.418 & 0.202 & 137.114 & 0.155 \\
\hline & PF & 0.053 & 9.413 & 1.295 & 0.06 & 27.493 & 0.502 & 0.101 & 132.472 & 0.175 \\
\hline \multirow{4}{*}{ 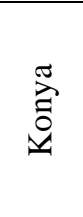 } & Fiberglass & 0.054 & 28.83 & 0.635 & 0.075 & 62.143 & 0.409 & 0.16 & 271.681 & 0.2 \\
\hline & EPS & 0.12 & 49.687 & 0.266 & 0.147 & 89.918 & 0.18 & 0.286 & 324.629 & 0.097 \\
\hline & GW & 0.119 & 51.432 & 0.243 & 0.145 & 92.18 & 0.165 & 0.282 & 328.788 & 0.09 \\
\hline & $\mathrm{PF}$ & 0.059 & 48.718 & 0.279 & 0.072 & 88.644 & 0.187 & 0.142 & 322.303 & 0.101 \\
\hline \multirow{4}{*}{$\stackrel{\pi}{\pi}_{i=1}^{n}$} & Fiberglass & 0.064 & 40.164 & 0.54 & 0.083 & 81.052 & 0.347 & 0.177 & 336.176 & 0.178 \\
\hline & EPS & 0.129 & 62.843 & 0.226 & 0.16 & 111.517 & 0.158 & 0.314 & 394.392 & 0.088 \\
\hline & GW & 0.128 & 64.73 & 0.208 & 0.158 & 113.985 & 0.146 & 0.309 & 398.946 & 0.081 \\
\hline & $\mathrm{PF}$ & 0.064 & 61.794 & 0.238 & 0.079 & 110.143 & 0.165 & 0.155 & 391.844 & 0.091 \\
\hline
\end{tabular}

*Non- energy savings are highlighted in Bold.

Figure 10 below shows the optimum insulation thickness versus present worth for LPG (in heating) and electricity (in cooling) for different insulation materials in city of Sanliurfa. The optimum insulation thickness increases with the increase of PWF, based on economic data. For the provinces chosen, Figure 11below shows variation of GW insulant thickness to be used individually for three fuels and energy saving $\left(A_{y e a r, H}\right)$ value in the event of utilization of $\mathrm{GW}$ insulant. Annual savings are inversely proportional to the costs of insulation materials. Therefore, it is possible to infer that energy savings diminish as the cost of insulation increases. When saving amount is compared for same insulation thickness, Sivas province is highest, and then Konya, Sanliurfa, and Antalya, respectively. Also, when the insulation thickness in Antalya reaches $0.2 \mathrm{~cm}$, the energy saving becomes zero. It is moreover observed that heating degree-day values of the provinces decrease accordingly. The change in annual fuel consumption in accordance with the increasing thicknesses of four different insulation materials in city of Antalya is shown in the following Figure 12 for (a) coal, (b) LPG and (c) natural gas as energy sources, respectively. For the city of Antalya, Figure 13 shows the effect of $\mathrm{CO}_{2}$ and $\mathrm{SO}_{2}$ emissions of coal as a fuel on the changing insulation thickness. As the insulation thickness increases, fuel consumption and emissions decrease. The lowest fuel consumption and emissions at all insulation thicknesses for three fuel types are obtained for phenolic foam (PF) insulation material with the highest thermal resistance, while the highest fuel consumption and emissions are obtained for fiberglass with the lowest thermal resistance. In addition, the annual fuel consumption and emissions of coal due to its low-cost are higher than those of LPG. 

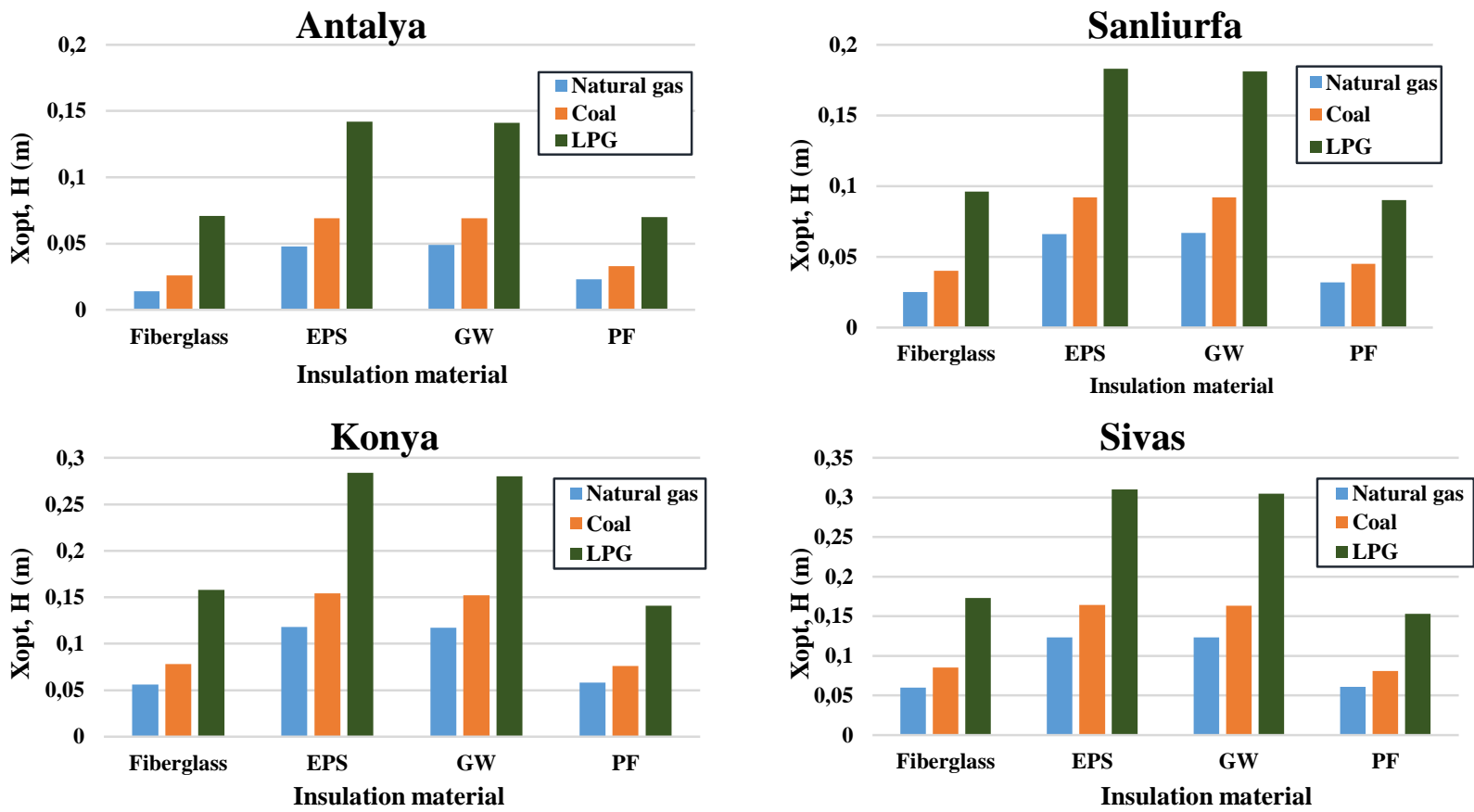

Figure 6. Optimum thicknesses of insulation materials to be used by fuels for heating only in cities examined
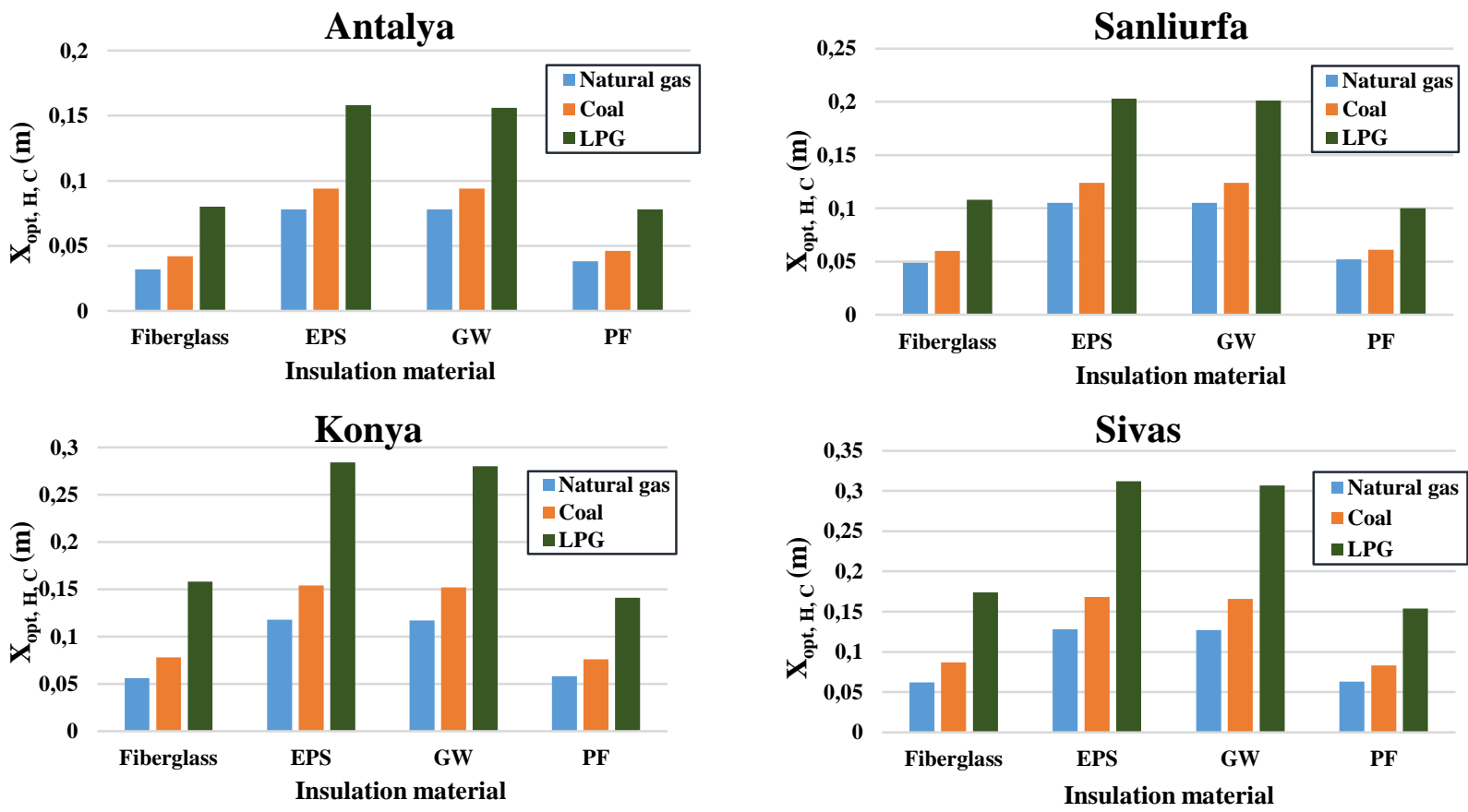

Figure 7. Optimum thicknesses of insulation materials to be used by fuels for both heating and cooling in cities examined
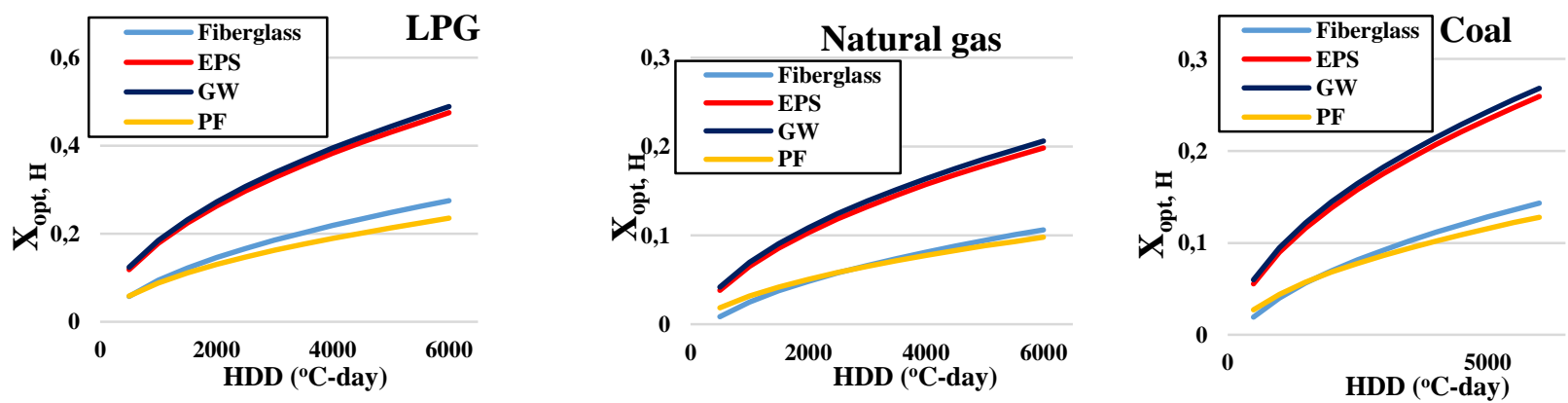

Figure 8. Optimum insulation thickness needed to be used by heating degree-day values for heating only 
Coal

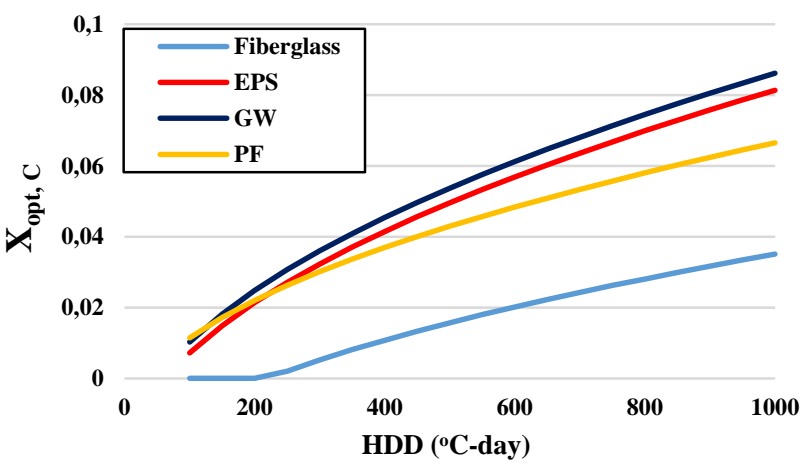

Figure 9. Optimum insulation thickness needed to be used by cooling degree-day values for cooling only

(a)

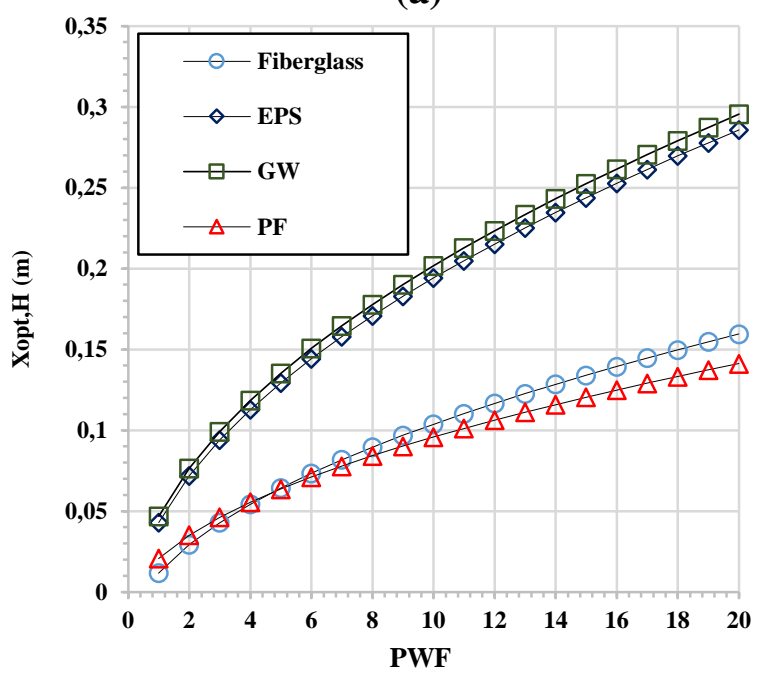

(b)

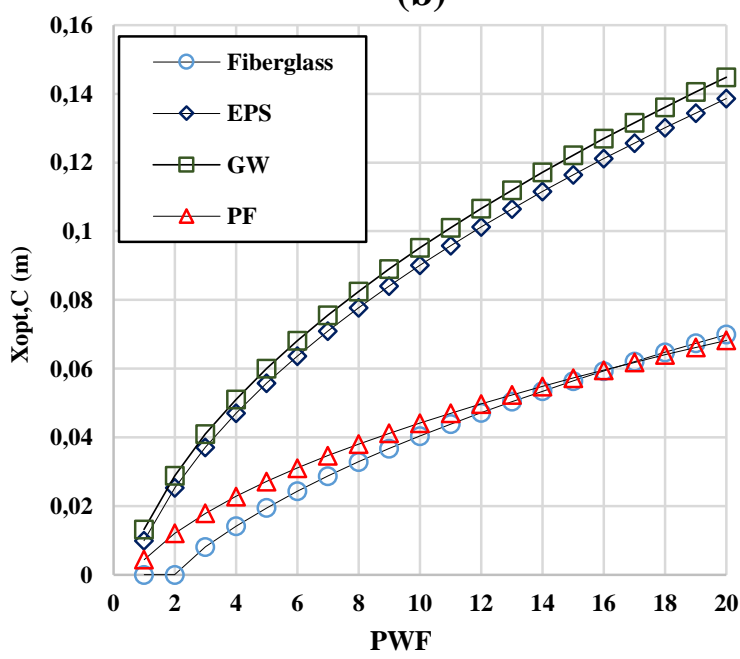

Figure 10. Optimum insulation thickness versus present worth factor for different insulation materials in Sanliurfa((a) LPG for heating purpose and (b) electricity for cooling purpose)

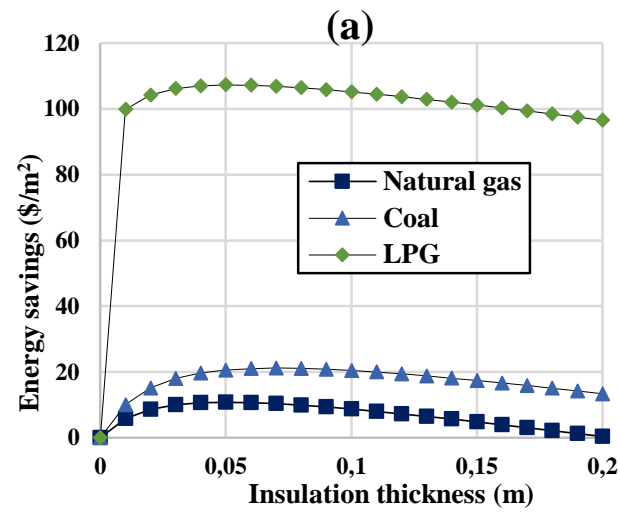

(b)

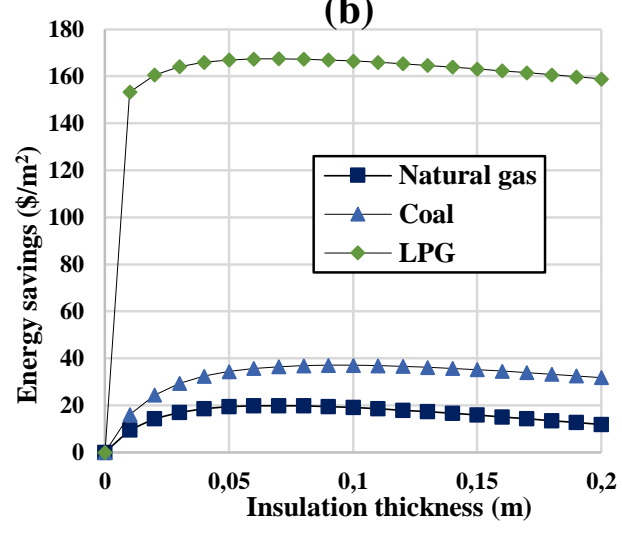

(c)

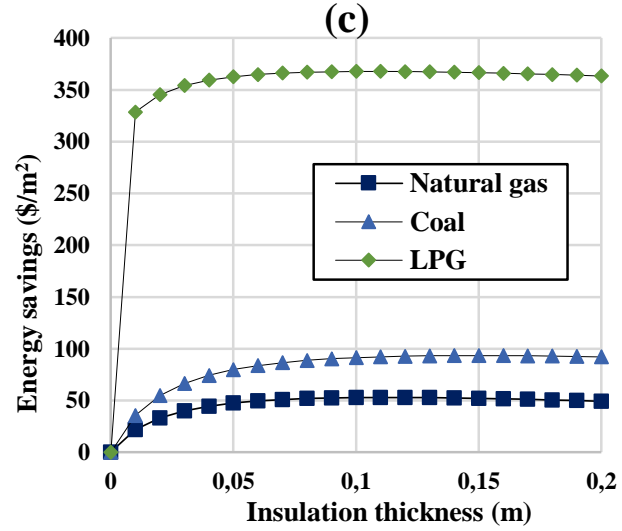

(d)

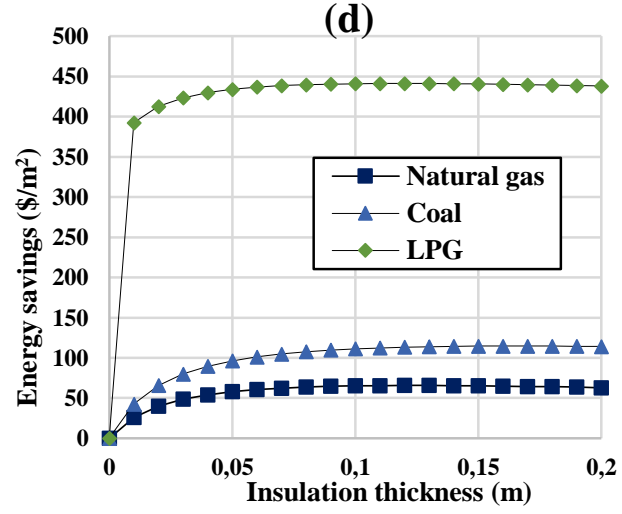

Figure 11. Energy saving $\left(\mathrm{A}_{\text {year,H}}\right)$ values with insulation thickness of GW by provinces((a) Antalya, (b) Sanliurfa, (c) Konya, and (d) Sivas) 
(a)

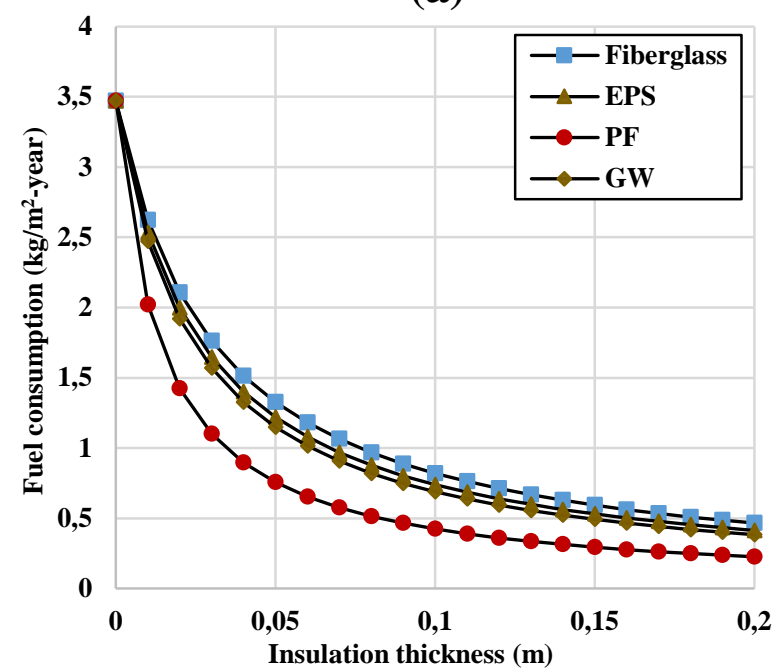

(b)

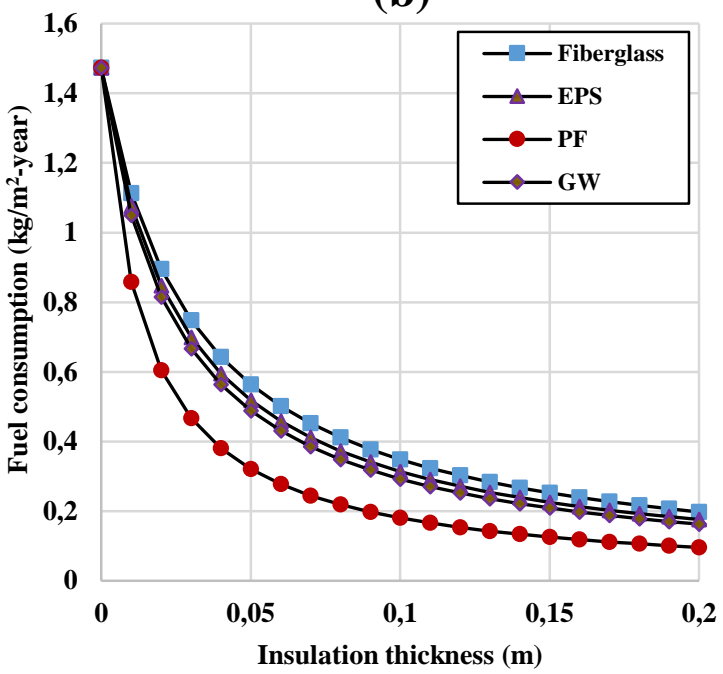

(c)

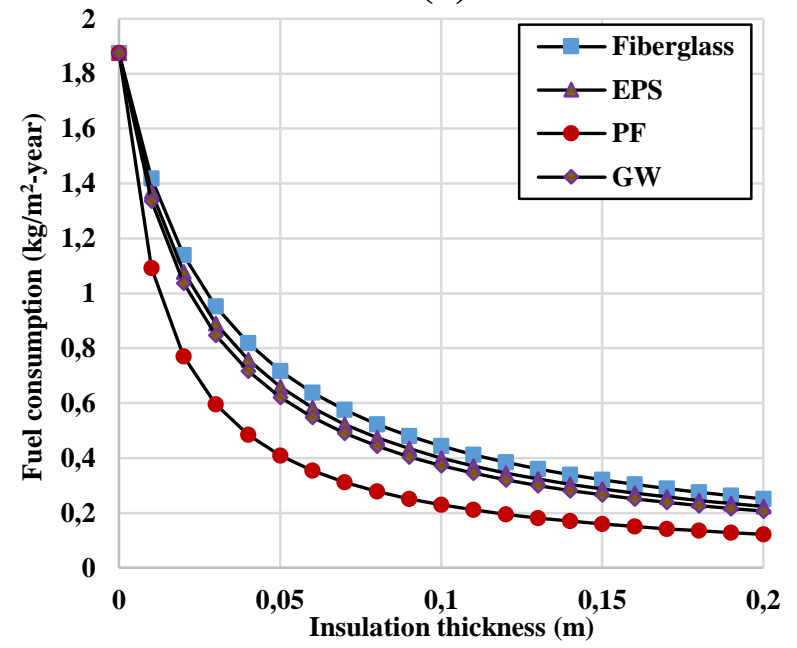

Figure 12. Change of annual fuel consumption ((a) coal, (b) LPG, and (c) natural gas)by increasing thickness of four different insulation materials in Antalya (a)

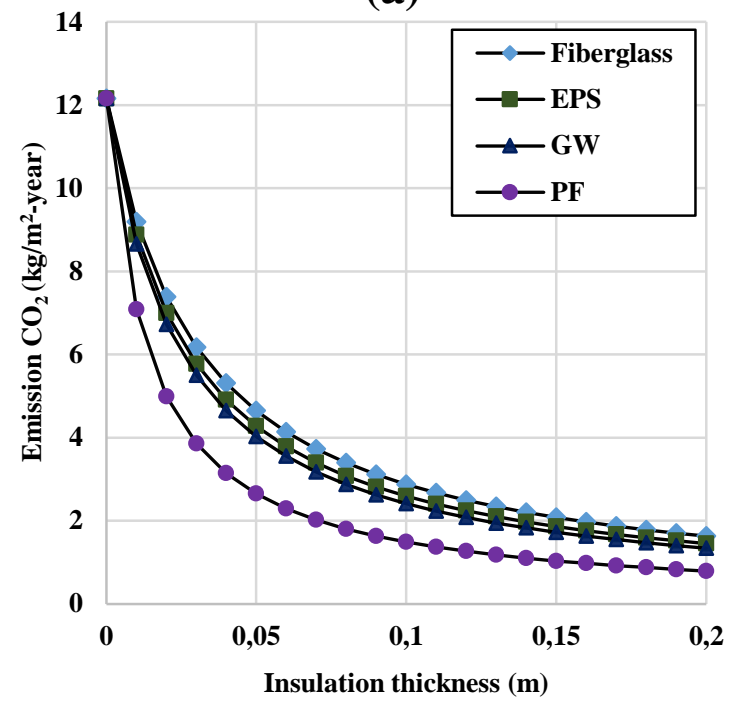

(b)

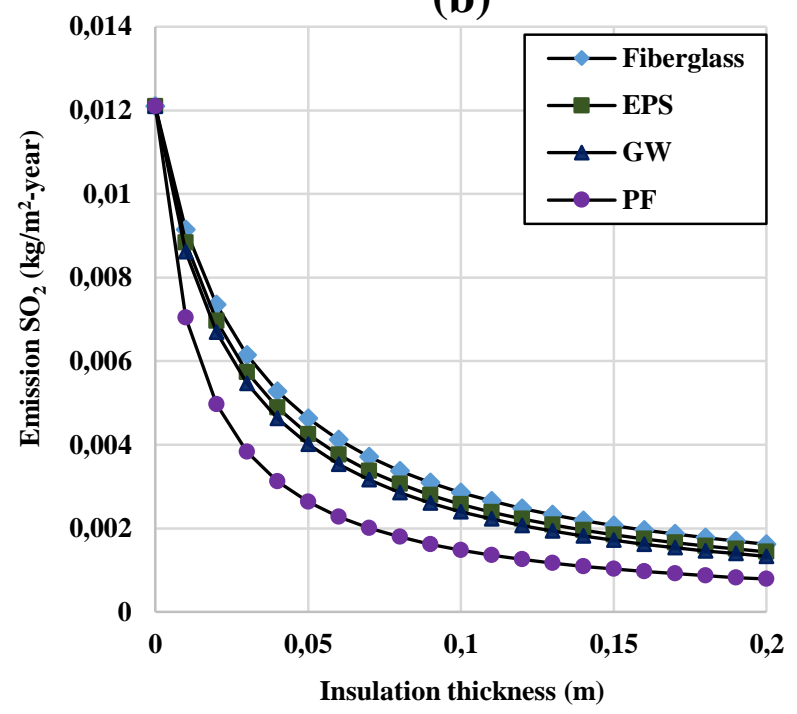

Figure 13. The effect of (a) $\mathrm{CO}_{2}$ and (b) $\mathrm{SO}_{2}$ emissions of coal on varying insulation thickness

In case optimum thicknesses of different insulation materials in different cities are employed, annual fuel consumption and emission amounts are given in Table 9 below. When coal as fuel is used, the consumption of fuel changes between 1.184 and $4.704 \mathrm{~kg} / \mathrm{m}^{2}$. The emissions resulting from the combustion of this fuel change between 3.133 and $12.762 \mathrm{~kg}$ $/ \mathrm{m}_{2}$ for $\mathrm{CO}_{2}$ and 0.004 and $0.0017 \mathrm{~kg} / \mathrm{m}^{2}$ for $\mathrm{SO}_{2}$. The lowest fuel consumption and emissions for four different provinces are achieved for glass wool $(\mathrm{GW})$ insulation material owing to its highest optimum insulation thickness, whereas the highest consumption and emissions are obtained for fiberglass insulation material due to its lowest optimum insulation thickness. It is seen from Table 10 below that reduction in emissions fluctuates between $45.65-86.81 \%$ for coal, $31.03-83.21 \%$ for natural gas and $69.64-92.49 \%$ for LPG, in the event of employing optimum thicknesses applied 
to the exterior walls of buildings for four cities in different degree-day regions.

\section{Conclusions}

The energy shortages experienced by many countries as a result of the rapid demand and consumption of energy have shown the importance of energy saving. Significant savings in energy can be achieved with insulation applications, especially in countries where the majority of energy requirements are met by imports. Thermal insulation applications on the exterior walls of buildings are extremely effective in reducing emissions of air pollution resulting from the use of fossil fuels as well as to save energy by reducing fuel consumption.

In this study, optimum insulation thicknesses, energy savings, payback periods, and environmental impacts of fuels burned were calculated for Antalya, Sanliurfa, Konya and Sivas cities in four different climatic regions of Turkey for buildings that are heated but not cooled, and both heated and cooled. When insulation materials at the optimum thicknesses are applied to the external walls, substantial energy savings and reductions in emissions were observed. The results verify that the optimum insulation thicknesses ranged from 1.4 to $30.5 \mathrm{~cm}$ for heating only, and varied between 3.4 to $31.4 \mathrm{~cm}$ for both heating and cooling. The amount of energy savings fluctuated from 1.91 to 368.58 $\mathrm{TL} / \mathrm{m}^{2}$ in the event of employing different fuel types for heating, changed between 2.74 and $399 \mathrm{TL} / \mathrm{m}^{2}$ in case heating and cooling requirements are provided together. Payback periods altered between 0.087 and 2.49 years for heated only in buildings, and vary between 0.081 and 3.28 years for heating and cooling together. The minimum emission resulting from the burning of energy sources was released with $0.96 \mathrm{~kg} / \mathrm{m}^{2}$-year in the event of utilization of LPG, while the highest emission with $11.7 \mathrm{~kg} / \mathrm{m}^{2}$-year was released in the event of utilization of coal. As a consequence of the study conducted, fiberglass as an insulation material is not economically feasible due to its high investment cost for Antalya in case of using coal and natural gas, and also not feasible for Sanliurfa in case of using natural gas as an energy source.

Table 9. Annual fuel consumption and emissions in case optimum insulation thickness is applied for insulation materials and fuel types for four cities in different degree-day regions

\begin{tabular}{|c|c|c|c|c|c|c|c|c|}
\hline \multirow{3}{*}{ City } & \multirow{3}{*}{$\begin{array}{c}\text { Ins. } \\
\text { Material }\end{array}$} & \multicolumn{3}{|c|}{ Coal } & \multicolumn{2}{|c|}{ Natural gas } & \multicolumn{2}{|c|}{ LPG } \\
\hline & & \multirow{2}{*}{$\begin{array}{c}\text { Fuel } \\
\text { cons. } \\
\left(\mathbf{k g} / \mathbf{m}^{2}\right)\end{array}$} & \multicolumn{2}{|c|}{$\begin{array}{c}\text { Amount of } \\
\text { emission }\left(\mathbf{k g} / \mathbf{m}^{2}\right)\end{array}$} & \multirow{2}{*}{$\begin{array}{c}\text { Fuel } \\
\text { cons. } \\
\left(\mathbf{k g} / \mathbf{m}^{2}\right)\end{array}$} & \multirow{2}{*}{$\begin{array}{c}\begin{array}{c}\text { Amount } \\
\text { of } \\
\text { emission } \\
\left(\mathrm{kg} / \mathbf{m}^{2}\right)\end{array} \\
\mathrm{CO}_{2}\end{array}$} & \multirow{2}{*}{$\begin{array}{c}\text { Fuel } \\
\text { cons. } \\
\left(\mathbf{k g} / \mathbf{m}^{2}\right)\end{array}$} & \multirow{2}{*}{$\begin{array}{c}\begin{array}{c}\text { Amount } \\
\text { of } \\
\text { emission } \\
\left(\mathbf{k g} / \mathbf{m}^{2}\right)\end{array} \\
\mathrm{CO}_{2}\end{array}$} \\
\hline & & & $\mathrm{CO}_{2}$ & $\mathrm{SO}_{2}$ & & & & \\
\hline \multirow{4}{*}{ Antalya } & Fiberglass & 2.437 & 6.611 & 0.009 & 1.669 & 4.417 & 0.578 & 1.940 \\
\hline & EPS & 1.264 & 3.429 & 0.005 & 0.874 & 2.314 & 0.305 & 1.024 \\
\hline & GW & 1.184 & 3.213 & 0.004 & 0.814 & 2.154 & 0.284 & 0.955 \\
\hline & $\mathrm{PF}$ & 1.331 & 3.611 & 0.005 & 0.914 & 2.420 & 0.316 & 1.060 \\
\hline \multirow{4}{*}{ Sanliurfa } & Fiberglass & 3.003 & 8.147 & 0.011 & 2.058 & 5.448 & 0.713 & 2.392 \\
\hline & EPS & 1.566 & 4.248 & 0.006 & 1.083 & 2.866 & 0.377 & 1.265 \\
\hline & GW & 1.460 & 3.961 & 0.005 & 1.004 & 2.658 & 0.352 & 1.181 \\
\hline & $\mathrm{PF}$ & 1.627 & 4.414 & 0.006 & 1.128 & 2.987 & 0.392 & 1.315 \\
\hline \multirow{4}{*}{ Konya } & Fiberglass & 4.311 & 11.697 & 0.016 & 2.976 & 7.879 & 1.037 & 3.482 \\
\hline & EPS & 2.283 & 6.194 & 0.008 & 1.576 & 4.172 & 0.551 & 1.849 \\
\hline & GW & 2.128 & 5.772 & 0.008 & 1.466 & 3.880 & 0.514 & 1.726 \\
\hline & PF & 2.365 & 6.416 & 0.009 & 1.636 & 4.330 & 0.571 & 1.916 \\
\hline \multirow{4}{*}{ Sivas } & Fiberglass & 4.704 & 12.762 & 0.017 & 3.241 & 8.580 & 1.135 & 3.811 \\
\hline & EPS & 2.498 & 6.776 & 0.009 & 1.719 & 4.550 & 0.601 & 2.018 \\
\hline & GW & 2.324 & 6.305 & 0.009 & 1.596 & 4.225 & 0.562 & 1.886 \\
\hline & $\mathrm{PF}$ & 2.586 & 7.015 & 0.01 & 1.770 & 4.687 & 0.624 & 2.095 \\
\hline
\end{tabular}


Table 10. Amount of reduction (\%) in emissions in case that optimum insulation thickness is applied to the external walls of buildings

\begin{tabular}{|c|c|c|c|c|c|c|c|c|c|c|c|c|}
\hline \multirow{3}{*}{ City } & \multicolumn{12}{|c|}{ Reduction in emissions (\%) } \\
\hline & \multicolumn{4}{|c|}{ Coal } & \multicolumn{4}{|c|}{ Natural gas } & \multicolumn{4}{|c|}{ LPG } \\
\hline & Fiberglass & EPS & GW & $\mathrm{PF}$ & Fiberglass & EPS & GW & $\mathrm{PF}$ & Fiberglass & EPS & GW & $\mathrm{PF}$ \\
\hline Antalya & 45.65 & 63.87 & 73.59 & 70.31 & 31.03 & 63.87 & 66.37 & 62.22 & 69.64 & 83.98 & 85.06 & 83.40 \\
\hline Sanliurfa & 56.37 & 70.85 & 78.79 & 76.36 & 44.59 & 70.85 & 72.97 & 69.62 & 75.61 & 87.11 & 87.96 & 86.60 \\
\hline Konya & 70.78 & 80.21 & 85.58 & 83.97 & 62.62 & 80.21 & 81.59 & 79.46 & 83.44 & 91.21 & 91.79 & 90.89 \\
\hline Sivas & 73.30 & 81.92 & 86.81 & 85.32 & 65.91 & 81.92 & 83.21 & 81.38 & 84.82 & 91.96 & 92.49 & 91.65 \\
\hline
\end{tabular}

Based on these data, the greatest energy savings for the four cities is achieved using LPG in comparison with the other energy sources, namely coal and natural gas. Climate conditions are also important in terms of energy conservation. It is observed that energy saving becomes more important in cold regions. Furthermore, the insulation optimum thickness at the externally insulated walls of buildings varies according to the number of heating and cooling degree-days and the insulation material employed.

\section{References}

[1] Aytac\& U.T. Aksoy, Enerji Tasarrufu iç ve Dış Duvarlarda Optimum Yalıtım Kalınlığı ve Isıtma Maliyeti ilişkisi, J. Gazi Univ. Fac. Eng. Archit., vol. 21, pp. 753-758, 2006.

[2] T. Keskin, "Enerji Verimliliği Kanunu ve Uygulama Süreci", Mühendis ve Makina vol. 569, pp. 106-112, 2007.

[3] N. Evcil, "Isı İzolasyonu ve Dış Duvarların Enerji Etkin Yenilenmesi", Yüksek Lisans Tezi, İstanbul Teknik Üniversitesi Fen Bilimleri Enstitüsü, İstanbul, 2000.

[4] A.Ulaş, "Binalarda TS 825 Hesap Yöntemine Göre Is1 Kaybı, Yakıt Tüketimi, Karbondioksit Emisyonu Hesabı ve Maliyet Analizi", Gazi Üniversitesi Fen Bilimleri Enstitüsü, Yüksek Lisans Tezi, Ankara, 2010.

[5] Dombayc1, M. Gölcü \&Y. Pancar, "Optimization of insulation thickness forexternal walls using different energysources", Applied Energy, vol. 83, pp. 921-928, 2006.

[6] Bolattürk, "Optimum insulation thickness for building walls with respect to cooling and heating degree-hours in the warmest region of Turkey", Building and Environment, vol. 43, pp. 10551064, 2008.

[7] N. Daouas, A study on optimum insulation thickness in walls and energy savings in Tunisian buildings based on analytical calculation of cooling and heating transmission loads, Applied Energy, vol. 88, pp. 156-164, 2011.

[8] K. Çomaklı \& B. Yüksel, "Optimum insulation thickness of external walls forenergy saving", Applied Thermal Engineering, vol. 23, pp. 473-479, 2003.

[9] Hasan,"Optimizing insulation thickness for buildings using life cycle cost", Applied Energy, vol. 63, pp. 115-24, 1999.

[10] M. S.Mohsen, \& B. A.Akash, "Some prospects of energy savings in buildings", Energy Conversion and Management, vol. 42, pp. 1307-1315, 2001.
[11] M. J. Al-Khawaja,"Determination and selecting the optimum thickness of insulation for buildings in hot countries by accounting for solar radiation", Applied Thermal Engineering, vol. 24, pp. 2601-2610, 2004.

[12] O. Kaynakl1,"A study on residential heating energy requirement and optimum insulation thickness",Renewable Energy, vol. 33, pp. 1164-1172, 2008.

[13] Uçar \& F. Balo, "Determination of the energy savings and the optimum insulation thickness in the four different insulated exterior walls", Renewable Energy, vol. 35, pp. 88-94, 2010.

[14] D. B. Özkan \& C. Onan, "Optimization of insulation thickness for different glazing areas in buildings for various climatic regions in Turkey", Applied Energy, vol. 88, pp. 13311342, 2011.

[15] Aktemur,"A Case Study for Estimation of Heating Energy Requirement and Fuel Consumption in a Prototype Building Using Degree-Day Method in Kocaeli", International Journal of Engineering Technologies, vol. 3, pp. 27-36, 2017.

[16] E. Gürel \& A. Daşdemir, "Türkiye'nin dört farklı iklim bölgesinde 1sıtma ve soğutma yükleri için optimum yalıtım kalınlıklarının belirlenmesi", Erciyes Üniversitesi Fen Bilimleri Enstitüsü Dergisi, vol. 27, pp. 346-352, 2016.

[17] N. A. Kurekci, "Determination of optimum insulation thickness for building walls by using heating and cooling degree-day values of all Turkey's provincial centers", Energy and Buildings, vol. 118, pp. 197-213, 2016.

[18] M. Ozel, "Cost analysis for optimum thicknesses and environmental impacts of different insulation materials", Energy and Buildings, 49, 552-559, 2012.

[19] N. Daouas, Z. Hassen\& H. B.Aissia, "Analytical period solution for the study of thermal performance and optimum insulation thickness of building walls in Tunisia", Appl Thermal Eng, vol. 30, pp. 319-326, 2010.

[20] M. Tolun, "Farklı derece-gün bölgeleri için yalıtım probleminin incelenmesi", PhD Thesis. Enerji Enstitüsü, 2017.

[21] Aytaç \& U. T. Aksoy, "Enerji Tasarrufu İçin Dış Duvarlarda Optimum Yalıtım Kalınlığı ve Isıtma Maliyeti İlişkisi", Gazi Üniversitesi Mühendislik Mimarlık Fakültesi Dergisi, vol. 21, pp. 753-758, 2006.

[22] O. Kaynakli, "A review of the economical and optimum thermal insulation thickness for building applications", Renew. Sustainable Energy Rev, vol. 16, pp. 415-425, 2012. 